\title{
Red coat, blue jacket, black skin: Aboriginal men and clothing in early New South Wales ${ }^{1}$
}

\author{
Grace Karskens
}

In 1819 a group of Aboriginal men from the Nepean River and the Blue Mountains came to Sydney, where they met some of the Frenchmen from the corvette Uranie. The French visitors were on a voyage of scientific discovery, and had planned a journey across the Blue Mountains. Most likely the Aboriginal men had agreed to act as their guides. Artist Alphonse Pellion sketched them at their camp on the edge of Sydney, and his drawings show that they were all wearing jackets or coats. Tara and Peroa, from the Nepean River, were not wearing trousers. Neither, probably, were the others - the engravings made from Pellion's sketches show them only from the waist up, and the Frenchmen noted with some shock that this was the usual manner of dress for the Aboriginal men in Sydney. ${ }^{2}$

Images of Aboriginal men wearing jackets or coats without trousers are common in colonial paintings from the late 1810s and in the 1820s. Whether the warriors in these pictures stand resplendent in silver braided scarlet, or slouch insouciant in torn, ill-fitting coats, most historians have interpreted the garments as sure signs of the low status of Aboriginal people in settler society. The jackets are indicative of a people reduced to beggary and drunkenness, of cultural annihilation, of a people without hope. These interpretations reach unbroken back to the responses of new or visiting colonists of the 1820s and 1830s (older colonists knew better). Around 1838 an anonymous rhymester - probably Baptist Minister and temperance advocate John Saunders - scribbled a poem at the bottom of an ugly caricature of Aboriginal people drinking and fighting. The third verse directly links the jackets with alcohol, violence and degeneration:

Now we see the end, these sans culottes

Decked with white mans cast off coats

Display their love in blows

One Gin with rum is stupefied

The second sups the infernal tide

Till basest passion glows ${ }^{3}$

1 Thanks to Tim Rowse and Brad Manera and two anonymous readers for their invaluable advice on this paper.

2 de Freycinet 2001[1824]: 123-124, 306; Quoy et al 1950[1819]: 7-12; Pellion 1819a, 'Sauvages de la Nouvelle Galles du Sud (d'apre nature dans leur Camp pres de Sidney (20 dec. 1819)', watercolour, Mitchell Library.

3 Saunders Rev John (attrib) c1838, poem accompanying 'Real Life in Sydney', lithograph, with letterbook 1834-1847, Mitchell Library, Sydney. 


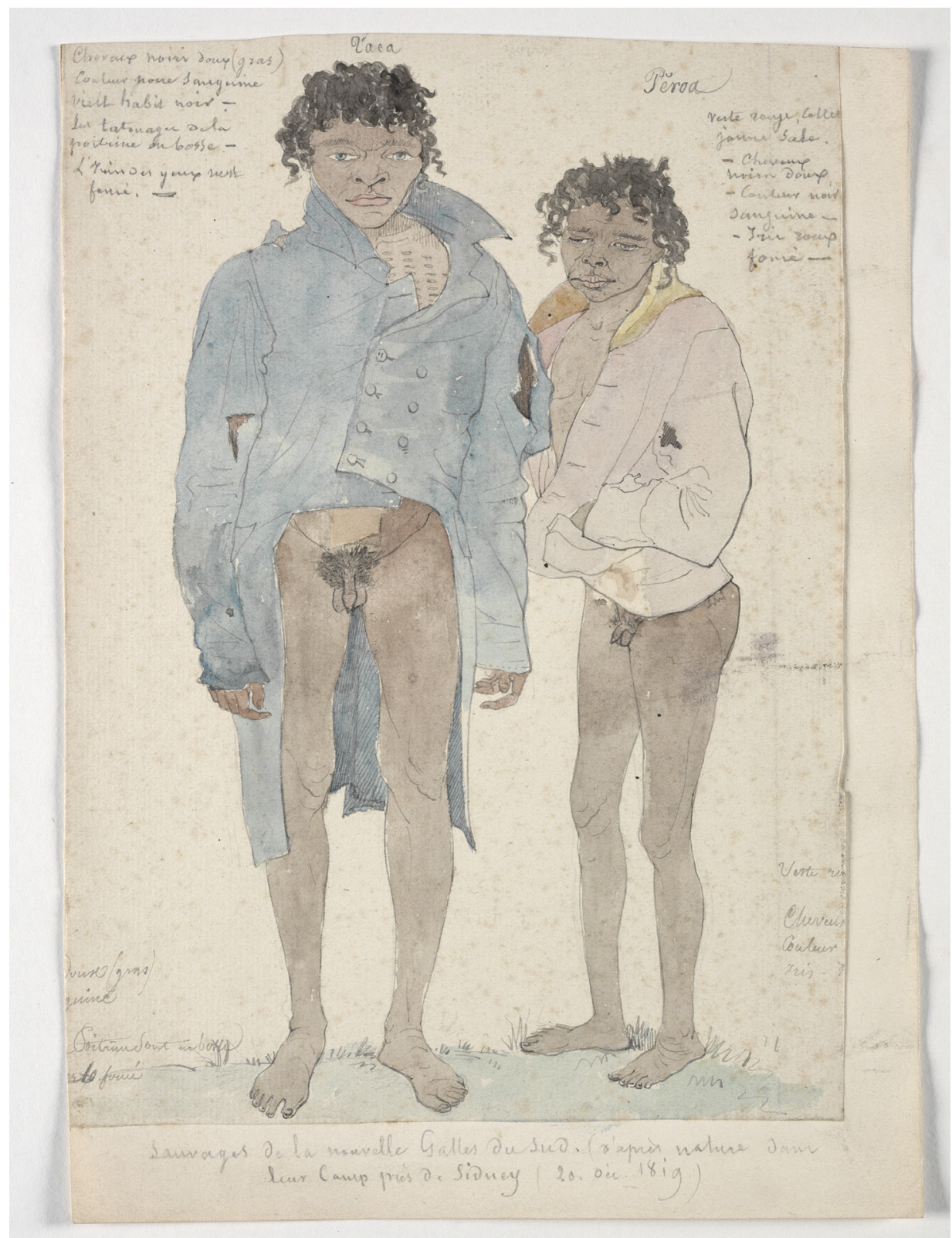

Fig 1. Alphonse Pellion (attrib), 'Sauvages de la Nouvelle Galles du Sud [Tara et Peroa]', watercolour, 1819.

Source: Mitchell Library, State Library of New South Wales, SV/118.

No doubt the term 'sans culottes' raised a smile among those who could remember the French Revolution. These tattered, motley urban Aborigines were without even the rough trousers of the Parisian militants - they were sans anything. Especially amusing and popular were the 'world-upside-down' 
cameos of key figures such as Bungaree, the famous leader and spokesperson of the 'Sydney Tribe', whose European finery contrasted ludicrously with his 'grotesque' face and bare feet. ${ }^{4}$

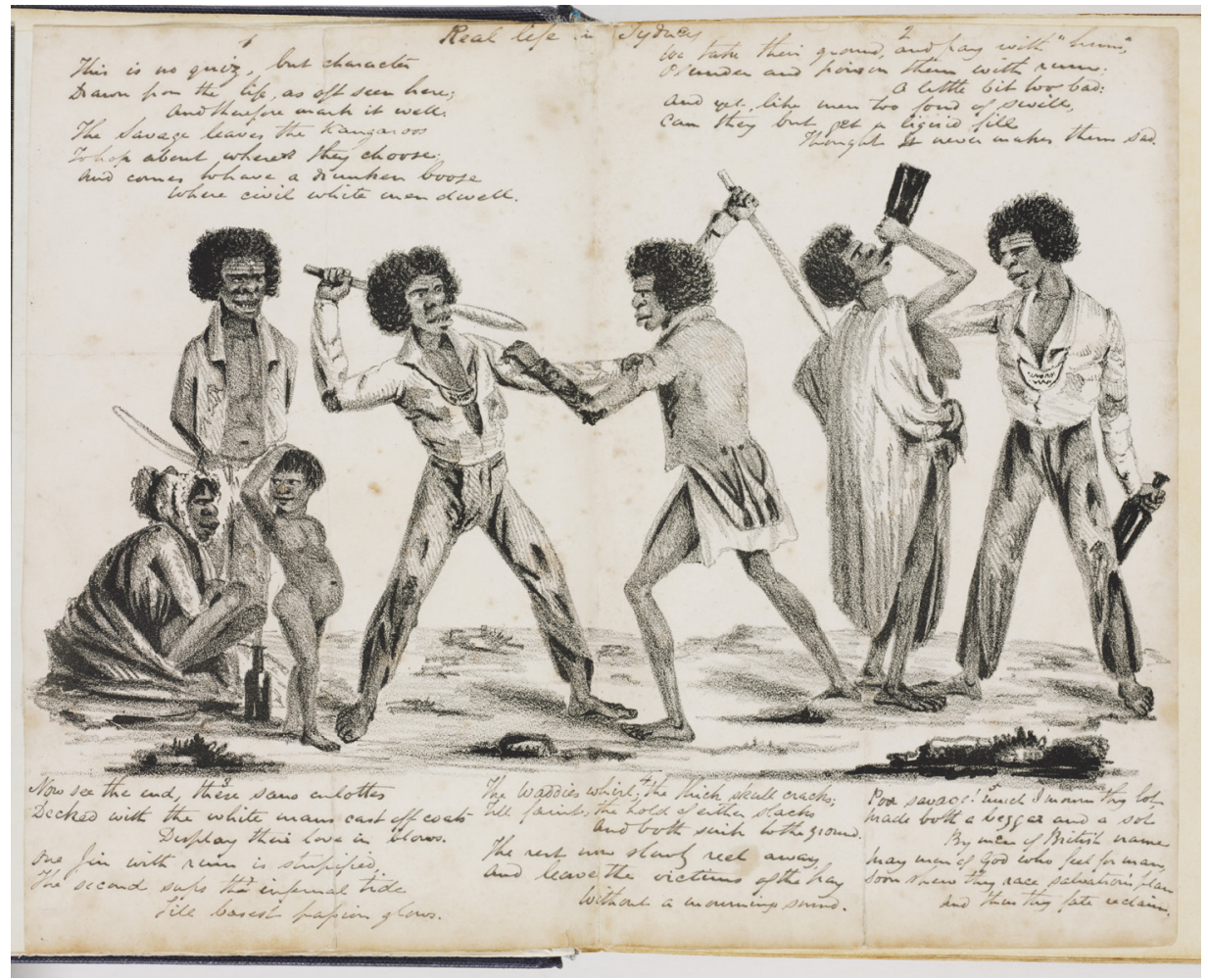

Fig 2. Artist unknown, 'Real life in Sydney', lithograph, c1838.

Source: Mitchell Library, State Library of New South Wales, B1106, with handwritten poem, very likely by Rev John Saunders.

Historians have used this contrast too, though here the purpose is not comedy but the revelation of dispossession and pauperisation. In his seminal White on Black, the first sustained study of white artists' depictions of Aborigines, Geoffrey Dutton wrote of Bungaree as beggar, mimic and drunk: 'When he wore the braided jacket and cocked hat given him by various governors, he had only to look down at his bare feet to know where he really stood' ${ }^{5}$ Writing in the aftermath of WEH Stanner's clarion call for historians to break the silence on Aboriginal dispossession, Dutton saw the fine red jacket as a sham, a bad joke. The bare feet tell us what is really going on.

Dutton's poignant words, like his chapter title, 'Instant Degeneration', set the tone and the conceptual approach for much of the commentary on Aborigines

4 Hansen 2007: 27-32.

5 Dutton 1974: 29. 
wearing European clothing. Art historian Michael Rosenthal concluded of the jacket-wearing Aboriginal man in Augustus Earle's 'Native Family Sitting Down on an English Settler's Farm' (c1826) that his 'carelessly-worn European attire and pipe smoking exemplify the radical incompatibility between the two cultures'. ${ }^{6}$ In her pioneering history of dress in Australia, Margaret Maynard applied a hegemonic model in which the dominant settler culture utterly supplanted the Aboriginal one. Here clothing was a weapon of coercion in the colonising process, forced upon naked Aboriginal people in order to civilise and subdue them. Maynard suggested an inverse relationship between European clothing and Aboriginal well-being: 'The adoption of European dress is likely to have aided in the destruction of Aboriginal culture through the undermining of self-esteem and erosion of health'. Those who chose to wear clothes did so only for 'expedience, a desire to please, or merely as imitation', and were savagely lampooned by whites for their trouble. So clothing could have no real meaning from an Aboriginal perspective. ${ }^{7}$

Keith Vincent Smith's sympathetic biography of Bungaree explored his extensive wardrobe of coats and hats in detail, as well as the way he wore them, his dignified demeanour and extravagant gestures. But in the end, Smith concurs with Dutton, and cites him: Bungaree, 'realising the hopelessness of his position and the loss of his heritage ... was determined to play it for laughs'. ${ }^{8}$ More recently, Craig Wilcox, in his lyrical cultural history of the British army in Australia, also meditated upon Bungaree and his coats. Most famous of course is the 'fine scarlet coat' he wore, together with 'the great cocked hat, the crimson sash, gleaming gorget', in Augustus Earle's 1826 oil portrait. Here, argues Wilcox, is evidence for 'Aboriginal aesthetics and ambitions too'. Yet he does not pursue this promising idea. Once more, the finery contrasts with Bungaree's expression, 'somewhere between regret and resignation' (in fact Bungaree smiles gently in this portrait). Other pictures reveal 'rapid decline', due not to advancing years but heavy drinking. So jacket-wearing remains empty mimesis: Aborigines were merely mimicking the red-coated soldiers, a rather pathetic appropriation of a key British symbol of power by 'people who now found themselves powerless'.

But look more closely at the paintings and sketches, especially those that were done on the spot. The men in them do not play the part of abject beggars or pathetic mimics. Jules-Louis Le Jeune's 1824 informal pen and ink sketch of Bungaree shows him wearing a long greatcoat and standing at the helm of his fishing boat, arm outstretched over the waves. His friends, either jacketed or naked, stand with their spears or pull at the oars of the boat. ${ }^{10}$ The men in Pellion's watercolours, Tara and Peroa, do not look like beaten refugees either. They stand relaxed, hands in the pockets of their oversized jackets, and meet the viewer's gaze full on, or casually look away.

6 Rosenthal 2000: 39.

7 Maynard 1994: chapter 4, 59, 70. See also Watson 1998.

8 Smith 1992: loc cit, quote 158.

9 Wilcox 2009: chapter 2, quotes 12, 13, 15, 123.

10 Le Jeune 1824. 


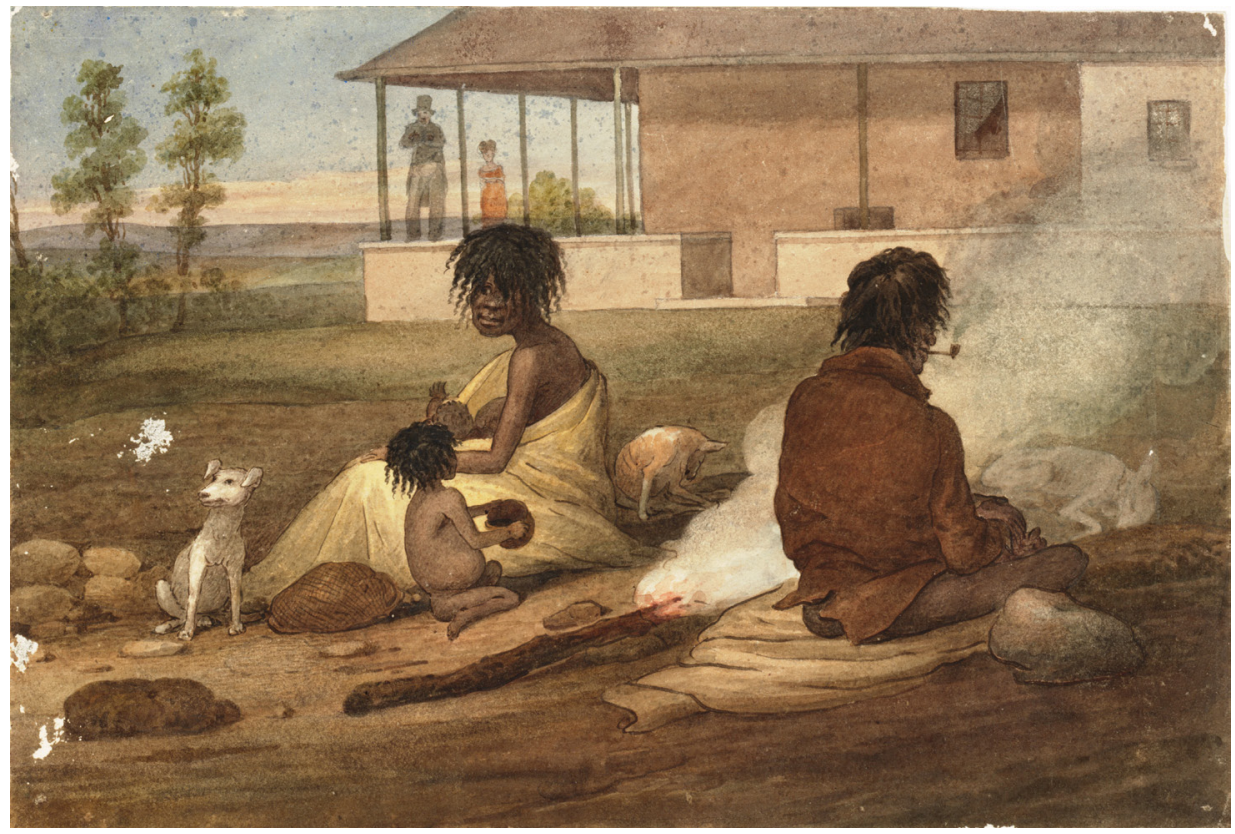

Fig 3. Augustus Earle, 'A native family of New South Wales sitting down on English settlers farm', c1826.

Source: National Library of Australia NK12/45.

Augustus Earle's watercolour of an Aboriginal family camped in front of a settler's house depicts the jacketed, trouserless man sitting cross-legged on a blanket on the ground with his back to the artist and the viewer, smoking a clay pipe, seemingly intent on his own business or thoughts, and uninterested in the white people around him. ${ }^{11}$ Earle's lithograph 'Natives of N. S. Wales as seen on the streets of Sydney' (which, like his other negative portrayals, appears to have been created later in England from earlier separate sketches) reveals a seemingly damning scene of degraded Aboriginal people drinking in the street. Yet even here, only two of the jacket-wearing men are drinking rum-and-water 'bull' from the bucket. The other jacketed man stands watching, and carries a traditional club. The women do not drink, and one carries a large fish, suggesting the continuance of women's traditional fishing. ${ }^{12}$

Perhaps Earle was responding to the growing taste for ugly caricatures of Indigenous people in this period. We can see this in the popular silhouette prints of the 1830s, where the ragged jackets were ever more closely associated with the 'corrosive effect of alcohol and dependence'. ${ }^{13}$ By the 1840s, Aboriginal people

11 Earle c1826, 'A native family of New South Wales sitting down on English settlers farm', watercolour, National Library of Australia.

12 Earle c1830, 'Natives of N. S. Wales as seen in the streets of Sydney', lithograph, National Library of Australia.

13 Thomas 1999: 58; Fernyhough c1836, 'A series of twelve profile portraits of Aborigines of New South Wales, drawn from life and on stone', silhouettes, 1840, 'Natives of NSW drinking Bull', 
were depicted wearing other articles of clothing as well - shirts, dresses and ragged trousers. But the image of the jacket worn without trousers recurred occasionally in art. Perhaps it was literal in Walter G Mason's picture of a public meeting in Sydney during elections in 1857, which includes a group of Aboriginal people listening to the speakers on the hustings. It made a vestigial appearance in ST Gill's 1866 caricature 'Native Dignity', which parodies Aboriginal appropriation of European finery, as well as the pretensions of the disconcerted respectable white couple in the background. ${ }^{14}$

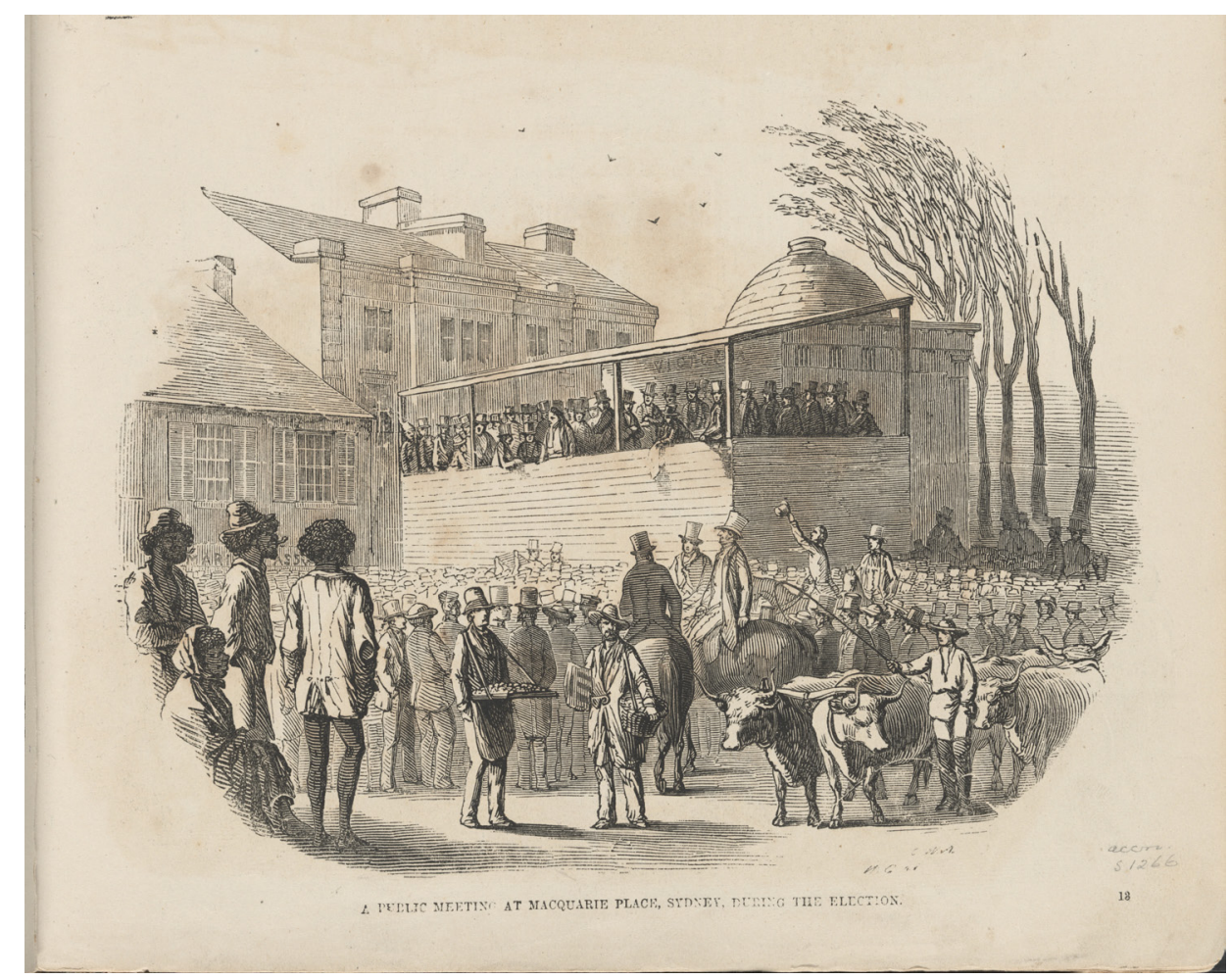

Fig 4. Walter G Mason, 'Public meeting at Macquarie Place, Sydney, during the election', print, wood engraving.

Source: National Library of Australia, PIC S1266.

silhouette, National Library of Australia; Nicholas 1840-42, 'Profiles of the Aborigines of New South Wales 1840-1842', silhouettes, National Library of Australia; Carmichael 1826, 'King of Black Natives', watercolour and ink, Mitchell Library; Phelps 1840, 'Native Scenes', pen and ink drawings, Mitchell Library.

14 Mason 1857, 'Public meeting at Macquarie Place, Sydney, during the election', print, wood engraving, National Library of Australia; Gill 1866, 'Native Dignity', lithograph, National Gallery of Australia. 


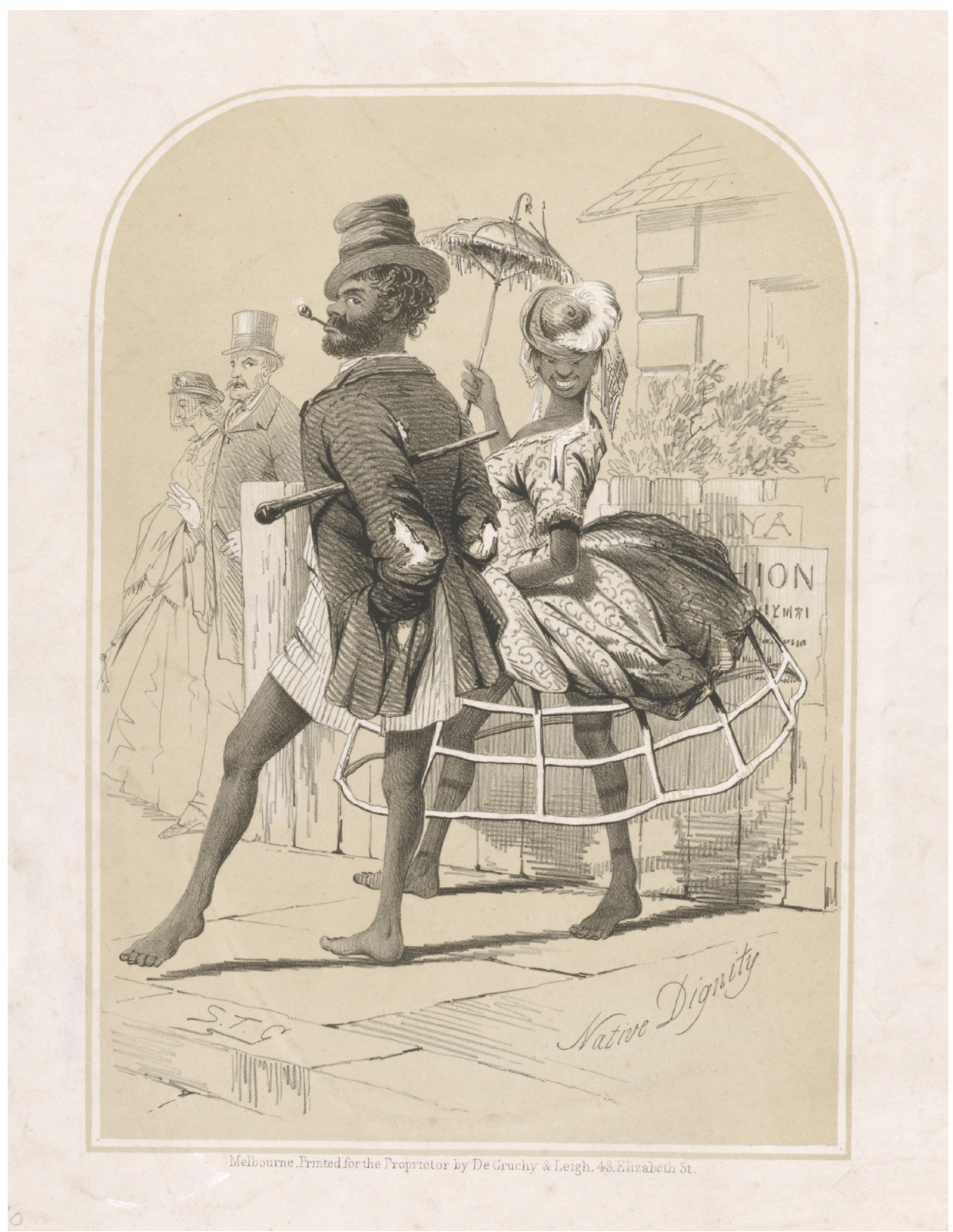

Fig 5. ST Gill, 'Native Dignity'.

Source: NK2459/6.

Given the long silence over Aboriginal history, and given the parlous state of many Aboriginal people in terms of life expectancy, standards of living and economic opportunities, it is not surprising that historians have seen these paintings and descriptions as damning evidence of a long, unbroken history of Aboriginal material and cultural impoverishment. But did Aboriginal warriors 
in the early colonial period consider themselves as degraded, culturally lost or outcast people? The pictures and the glimpses we have of them suggest something else, something more. In any case, does putting on a jacket, or wrapping oneself in a blanket, indicate 'instant degeneration' and culture loss, or at best a black sort of humour? If bare feet, and sitting down together on the ground, were customary among Aboriginal people, do they reveal only poverty and deprivation? Is mimicry always meaningless, merely reinforcing the power of the invaders? What if we track and reconsider this practice of jacket-wearing as a way of exploring the Aboriginal world, and the ways Aboriginal men in particular responded to the invasion of 1788 ?

Clothing and appearance signify boundaries and identity, as Maynard points out, but they are also instant visual codes triggering underlying assumptions about race and culture. ${ }^{15}$ Tim Rowse has written of such 'unsettling' moments, as a 'crisis of the conventions of perception'. But he argues that such moments are also a way to explore 'others' imaginations and ways of life' as well as our own. The things we do not understand, things that unsettle us, are precisely those which reveal most clearly 'the "interfering glosses" through which we look'. ${ }^{16}$

Rowse opens his study of Aboriginal men and clothing by recounting the visit of two eminent judges, John Kerr QC and Justice Richard Kirby, to a cattle station in Arrernte country near Alice Springs in 1965. They were there as part of the Commonwealth Conciliation and Arbitration Commission's inquiry into whether Aboriginal pastoral workers were to be included in the Northern Territory Cattle Industry Award. Kirby was head of the Commonwealth Conciliation and Arbitration Commission, and Kerr was representing the pastoralists, who argued that the increased wages were unjustified. Expecting to find the Aboriginal workers living in the 'bucolic contentment' that white pastoralists had described, Kirby and Kerr were taken aback to find the people poorly dressed, in 'dreadful sort of half-world clothes ... such as old army jackets, which make them half white man and half native'. Rowse points out that the white men turned away from this unsettling evidence, retreating instead into romantic representations of Aboriginal workers in handsome cowboy clothes, such as the works of Darryl Lindsay and Russell Drysdale, which 'retained their masculine dignity' within colonial pastoralism. ${ }^{17}$

Rowse's analysis of the uses and meanings of cowboy clothing offers some key insights into the way Aboriginal men and clothing might be explored. First, Kerr and Kirby appear to have experienced something of the same disquiet as observers in Sydney in the 1820s when they saw Aboriginal men wearing old jackets. Here, then, are Rowse's 'glosses': Europeans expected, and perhaps still expect, to see either 'pristine hunter' or Aborigines wearing clothes in the

15 Maynard 2006: 103.

16 Rowse 1991: 1-2.

17 Rowse 1991: 3-4. 
European manner. Hybrid dress signals something in between, something not easily definable. It is precisely this disturbing glimpse, this 'something in between' that leaves room for an Aboriginal side of the story. ${ }^{18}$

Second, Rowse examines the role of cowboy clothes by reading them within the wider gendered, political and economic contexts of the Northern Territory pastoral industry. The meanings and significance of clothing worn by Aboriginal men cannot be generalised across time and place - they are enmeshed in, and therefore contingent upon, particular historical contexts. ${ }^{19}$ Thus, an old, torn coat might well reveal poverty in one circumstance, but can signify something quite different in another. Philip Jones argues similarly that the nature of frontier encounters depended on circumstance, particular actions, myriad variables. It is necessary therefore to look carefully at the 'moment of exchange', and to see that 'frontiers were loaded with other possibilities'. ${ }^{20}$

Jones demonstrates that the artefacts of frontier encounter and collection themselves carry information: they are 'the chains along which social ideas run'. Ethnographic artefacts which 'crossed over' may well reveal 'ideas generated within the Indigenous culture of origin'. What of European artefacts, like glass, metal hatchets and clothing, which crossed the other way, and were adopted and adapted by Aboriginal people? What can they reveal or suggest about Aboriginal culture response and world-view 'from within'? ${ }^{21}$

But here is a further difficulty. Flaked glass and metal blades may make it into public collections, but as Margaret Maynard points out, dress generally is marginalised in such collections. Even within such assemblages, 'working clothes, prisoners' clothes and European-influenced Indigenous clothes are rare inclusions'.$^{22}$ The jackets worn by warriors have not survived, the artefacts are absent. It is not possible to see or touch the real fabric, study the colour, cut, stitching, buttons, piping, braid, the tears and stains. These coats and jackets are ghost artefacts, recorded only in the paintings and words of white people, and then often conveyed through thick lenses of ridicule, revulsion or pity.

Jacket wearing by Aboriginal warriors in the early colonial period is a practice lost to history, just as these garments themselves have long disappeared. Yet these repeat glimpses are a faint but insistent leitmotif. In tracking them something more might be recovered about the encounters between colonists and Aboriginal people, the lived texture of negotiated lives and spaces in the early colony. What 'forgotten codes and protocols', and what larger scenarios of negotiation or accommodation - or cultural adaptation - might jacket-wearing suggest? ${ }^{23}$

18 See also Brock 2007: 1; Jones 2007: 11-12.

19 Brock 2007; Land 2006; Kovacic 2006.

20 Jones 2007: 5-6.

21 Jones 2007: 6-7.

22 Maynard 1991: 77.

23 Jones 2007: 6. 
Jackets and coats were significant objects during the earliest encounters between the Berewalgal and Eora in January 1788. After Governor Phillip and his party had broken the ice by ritual gift-giving, some Kamaygal (the people of Botany Bay) came forward to inspect the strangers more closely. They were particularly curious about the clothes, as Surgeon George Worgan wrote later, 'feeling the Coat, Waistcoat, and even the Shirt and on seeing one of the Gentlemen pull off his Hat, they all set up a loud Hoop'. ${ }^{24}$

What struck the Berewalgal, on the other hand, was the sight of so many 'perfectly naked' people, walking about as if being stark naked was the most normal thing in the world. The newcomers, who were accustomed to wearing a number of layers of clothing, associated wearing clothes with being 'civilised', while being unclothed was an instant marker of 'savagery'. The unclad body triggered a whole range of responses: the most basic was that it indicated a total lack of 'modesty'. ${ }^{25}$ The First Fleet officers also saw it as evidence of the poverty and deprivation of the savage state. Giving these poor creatures clothing was thus an act of kindness and charity.

Here we encounter a linguistic and conceptual gap. The Eora may have been unclothed, but they were not naked, for they dressed their bodies in many complex and distinctive ways. As Ian Gilligan points out, 'dressing (rather than clothing) the body is a universal feature of all known human cultures', so there can be 'no such thing as nakedness' ${ }^{26}$ In the Sydney region, each of the more than 30 groups of Aboriginal people dressed their bodies in distinctive ways. Men and women were marked by with cicatrices (raised scars) in distinctive patterns on their chests and arms. They painted their bodies with clay: white for corroborees, red for war, contests and mourning. Men everywhere wore long beards, but the different groups were distinguished by their hairstyles. Those from the Botany Bay area gummed their hair in dreadlocks, which to the Berewalgal looked like 'the thrums of a mop'; other groups adorned their hair with the teeth and the tails of animals. Men and women sometimes wore multistranded necklaces made of dried reeds, or cascades of kangaroo teeth. Initiated Eora men of the coastal Sydney region were also marked by a missing front tooth, while women had lost the top two joints of the little finger of their left hands. Many had pierced septums, for wearing small bones or sticks. ${ }^{27}$

As for clothing, the groups of the colder, higher regions to the south wore possum fur cloaks, slung over the shoulders, fastened at the front. But in the Sydney region, apart from the barin, or apron, worn by prepubescent girls, and the string waistband in which warriors carried their tools, the Eora wore no clothes at all. Their sex could thus be instantly gauged. However, as the Berewalgal

24 Worgan, George, letter to Richard Worgan, 12-18 June 1788, with journal fragment 20 January 1788 - 11 July 1788, Mitchell Library.

25 Russell 2010: 34.

26 Gilligan 2008: 487.

27 Collins 1971[1798], 1: 551-552; Worgan, George, letter to Richard Worgan, 12-18 June 1788, with journal fragment 20 January 1788 - 11 July 1788, Mitchell Library: 9; Attenbrow 2002: 107-111, 118. 
gradually realised, modesty was nevertheless part of Eora women's culture. Their customary way of sitting was with one leg bent and the foot covering the genitals. ${ }^{28}$ For men, though, there was no such consideration: in fact it was vitally important that their manhood be visible.

In fact the Eora probably did not possess a concept of nakedness, or a word for naked..$^{29}$ The Berewalgal's layers of strangely textured and coloured (and no doubt pungently odorous) clothing must have seemed like so many extra skins. And removing what looked like part of one's head to reveal hair underneath must have been astonishing. No wonder they whooped in amazement. But these extra skins stopped the process of encounter and communication dead in its tracks, because the Eora warriors and elders could not tell if these pale creatures were men or women: they had no beards and their genitals were hidden. Eora society was deeply gendered. Men dealt with men, though often the negotiations revolved around women. The truth, first revealed when a sailor was ordered to drop his trousers, elicited another great whoop: they are men! ${ }^{30}$ Physical appearance - clothing, lack of clothing, hairstyles, scars, tattoos, painted skin, beards and clean-shaven chins - thus profoundly shaped the encounters for both peoples, and would continue to do so over the long colonial period.

Not long after the first encounter in Botany Bay, a jacket was given as a sign of friendship - though not by the official party, but ordinary sailors who went on shore to meet the Kamaygal. Unlike their superiors, the sailors were 'without Arms or any thing to protect themselves, sailor like'. They met men, women and children who were very friendly, and who 'eagerly accepted of a Jacket which one of the sailors gave them' ${ }^{31}$ It was probably a blue sailor's jacket, either brought along deliberately, as a gift; or perhaps peeled, still warm, from the wearer's back. Even if the coat was of little practical use to the Kamaygal, it was obviously an item the strangers held in some esteem, for they all wore them. As a gift it was clearly a sign of friendship. Since exchange and gift-giving was common to both cultures, both groups understood this ritual. ${ }^{32}$

Meanwhile relations were also being wrought by the governor and officers. Instructed to treat the natives kindly and 'live with them in amity', they were trying to keep the upper hand in managing cross-cultural relations, as well as attempting to prevent contact between convicts and sailors (whom they saw as brutal) and Aborigines. ${ }^{33}$ But it was through the officers' efforts that certain jackets - the soldiers' red coats - soon developed very different meanings. They were associated not with friendship and amity but with danger and violence. These

28 Collins 1971[1798], 1: 562, 457; Attenbrow 2002: 109; Brock 2007.

29 Cf Donaldson 1985; Kohen 1993: 208-262.

30 Bradley 1786-1792: 60, 63; Worgan, George, letter to his brother Richard Worgan, 12-18 June 1788, with journal fragment 20 January 1788 - 11 July 1788, Mitchell Library: 4, 9; King 17861789: entry 20 January 1788.

31 Bradley 1786-1792: 61.

32 Worgan, George, letter to Richard Worgan, 12-18 June 1788, with journal fragment 20 January 1788 - 11 July 1788, Mitchell Library: 2; McBryde, 1989: 169-182.

33 Governor Phillip's Instructions, 27 April 1787, in Watson 1914-1925, Historical Records of Australia, series 1, vol 1: 1, 13-14; White 1962[1790]: 109. 
Berewalgal's gestures of peace were always performed under the watchful eyes of red-coated soldiers and sometimes accompanied by demonstrations of the might of their weaponry. Musket balls were fired through the hardwood shields (elemong) the Eora warriors used to protect themselves in battle. As Lieutenant Watkin Tench coolly remarked, 'Our first object was to win their affections, and our next was to convince them of the superiority we possessed: for without the latter, the former we know would be of little importance' ${ }^{34}$ The natives were to be treated kindly, but they had to be shown exactly where they stood. The Eora understood the gun part perfectly.

Unsurprisingly, then, the red coat soon became a sign of danger. 'They know and dread the superiority of our arms', wrote Surgeon John White, for 'they carefully avoided a soldier - or anyone in a red coat'. ${ }^{35}$ The colour red was also significant in Eora culture: painted in clay on the body, it was the colour of anger, revenge, fighting and mourning. The messengers who ran from one country to another with news were painted red too: it signalled important events, it was the colour of alarm, of warning. ${ }^{36}$ Soon the mere sight of the soldier's red coat caused the Eora to melt into the bush, so preventing any opportunity for contact, let alone friendship. The officers were disappointed. After all the initial friendly overtures and meetings, and all those gifts, the Eora avoided the Camp at Sydney Cove for months.

But by May 1788, Eora warriors were stealing convicts' jackets, often while the latter worked cutting timber or rushes on the harbour. The earliest recorded incident occurred near Balmain, upriver from Sydney, and it had terrible consequences:

Some Canoes landed at Major Ross Garden up the Harbour, they stole a Jacket \& several other things which were afterwards found in one of the Canoes by some of the Convicts who followed them along the shore to the next Cove where they landed... ${ }^{37}$

Rumours that the pursuing convicts killed an Aboriginal warrior soon spread, and may explain the first killings of convicts shortly after: payback attacks on two rush cutters working in the same area. One was beaten to death, the other appeared to have died of shock. ${ }^{38}$

Thefts of jackets continued, and they infuriated the convicts. In January 1789 another party of rush cutters working down the harbour found that three jackets

34 Hunter 1968[1793]: 39; White 1962[1790]: 111; Worgan, George, letter to Richard Worgan, $12-$ 18 June 1788, with journal fragment 20 January 1788 - 11 July 1788, Mitchell Library: 3; Tench 1979[1789/1793]: 35, 37, 50 .

35 White 1962[1790]: 110, 111; Clark, Ralph, letter to Lt William Collins, 1 October 1788, Letterbook, Mitchell Library.

36 Tench 1979[1789/1793]: 278; Smith 1992: 143.

37 Bradley 1788.

38 White 1962[1790]: 132, 134; Worgan, George, letter to Richard Worgan, 12-18 June 1788, with journal fragment 20 January 1788 - 11 July 1788, Mitchell Library: 33; Collins 1971[1798], 1: 16-17, 30-31; Tench 1979[1789/1793]: 50. 
had been taken from their boat, the two culprits paddling away like lightening. Their coxswain set off in pursuit, and, finding the jackets in a canoe beached on a small island, reclaimed them and stole the canoe as well. His boat was followed by a hail of spears from the enraged Eora men. ${ }^{39}$

At this early stage the thefts may have been opportunistic. Jackets, unlike trousers, were the items left lying about when it was hot. It might have been retaliation for the convicts' and sailors' thefts of Eora tools and implements they found about the camps 'to sell to the people on the transports'. ${ }^{40}$ The European objects the Eora desired - and later demanded - were usually practical things, like steel axes and fish hooks, food and drink, while they left the useless beads and mirrors on the sands. So jackets seem odd things to target. They may have seen them potential trade items, adding them to the other goods that passed from hand to hand along the customary trade routes up and down the coast and between the coast and the interior. But as shown, the Eora of the Sydney coastal region did not customarily wear clothes, even when they were cold, so it is unlikely that they were wanted for warmth or protection. In any case these garments would at first have been extremely uncomfortable if not completely impractical for such active people, who used their backs, shoulders and arms constantly for paddling canoes, carrying children, for throwing spears with deadly accuracy, for parrying with shield against the spears of enemies. One man who tried on a shirt seemed 'appeared to be deprived of the use of his limbs' ${ }^{41}$ Wearing a jacket would have involved considerable discomfort and a sacrifice of mobility, at least in the beginning. What could have induced warriors to want, and then wear, such a garment?

By early 1790, the Eoras' keenness on jackets had filtered through to the higher echelons of the colony. On one harbour outing Phillip and his companions saw a group of women on a point near Rose Bay (Pannerong). They 'throw'd ... a Jacket \& several other things' onto the beach there. Phillip might have been thinking of an early excursion he made in Broken Bay, when a woman had wanted his greatcoat so badly, she sang, danced, flirted, wheedled and wept for it, all to no avail. Later he ordered men's frocks and jackets for the Eora, writing that 'these would do for men and women alike' ${ }^{42}$ But it was men alone who would commandeer jackets.

In the boat with them that day off Rose Bay was an Eora man, Woollarawarre Bennelong. Relations had fallen to such a parlous state during the previous year that Phillip resorted to kidnapping warriors in order to force open a means of communication. The young man Bennelong, grabbed from the beach at Manly in November 1789, proved to be an enthusiastic student and admirer of everything the Berewalgal showed him. Phillip dressed Bennelong over-warmly in a coat in an attempt to alter his physical sensibilities, to make him feel the cold, and so

39 Collins 1971[1798], 1: 52.

40 Collins 1971[1798], 1: 17, 23, 37.

41 Hunter 1968[1793]: 107.

42 Bradley 1790: entry 3 February; Worgan 1788: 25; Phillip cited in Maynard 1994: 62. 
come to know his own nakedness. ${ }^{43}$ This first coat was thus a tool employed to civilise the native. It was red, like those of the soldiers, though not made of fine felted wool, but 'the coarsest red Kersey', a primitive sort of fabric. ${ }^{44}$ Bennelong eventually rejected it. He escaped from Government House in May 1790, leaving his clothes behind. The governor and officers were deeply disappointed: another cross-cultural experiment seemed to have failed.

But four months later Bennelong summoned Phillip to meet him on Manly beach, and a boat was hurriedly loaded with 'wine, beef and bread, and a jacket or two', as well as knives. ${ }^{45}$ Jackets played an important, symbolic role at this meeting. Bennelong was presented with two jackets, one each by Phillip and David Collins, and he put them both on. Another warrior Coleby, a rival of Bennelong's, who had been kidnapped with him, but escaped, was also presented with a jacket, but he 'held [it] in his hand, not knowing how to put it on himself'. Not to be outdone by Bennelong, Coleby 'begged [Lieutenant Waterhouse] to put on the jacket which had been given ... which Mr Waterhouse did for him' ${ }^{46}$ It would have been quite a feat, for these were older-style military coats, long at the back and each as heavy as a blanket. ${ }^{47}$ Nevertheless, these gifted jackets, while certainly second hand, were not ragged cast-offs, or made of crude fabric. Wearing them may have reinforced the warriors' status as leaders and diplomats; it was also a sign of goodwill and politesse towards the Berewalgal.

Then, suddenly, the conversation and good relations evaporated. Phillip was steadily surrounded by warriors and then speared in the shoulder by a man he did not know. ${ }^{48}$ The jackets and other gifts did not protect him, for they did not deter the warriors from what appears to have been the true purpose of the meeting: ritual punishment.

The spearing, though terrifying, in fact marked a turning point in relations. Phillip recovered quickly, and within weeks a significant reconciliation took place on a beach on the north shore opposite Sydney in November 1790. Bennelong and his new wife Barangaroo, their friends and family, received visits from parties of officers bearing gifts and food - and jackets. Bennelong was presented with many gifts, but the one that 'pleased him more than anything else' was yet another jacket: a military red coat with silver epaulets. ${ }^{49}$

Gifts of jackets were not without precedent in British imperial history. Craig Wilcox points out that in North America, 'giving red coats to Indian confederates in the perpetual frontier fighting against other Indians or against the French and Spanish was common'. They were strategic gifts, meant to forge alliances in the

43 King 1786-1790: 395; Clendinnen 2003: 108-109.

44 King 1786-1790: 395; National Museum of the American Indian, 'Wool Trade Cloth in the Collection of the National Museum of the American Indian, Glossary', 2001, <http://www. nmai.si.edu/wooltrade/glossary.shtml>.

45 Hunter 1968[1793]: 141.

46 Hunter 1968[1793]: 141.

47 Brad Manera, pers comm, 16 March 2011; see Fosten 1989: 27, loc cit; Smith 2007: 97.

48 Phillip, in Hunter 1968[1793]: 307-308.

49 Phillip, in Hunter 1968[1793]: 311. 
'embattled beachheads [of] Massachusetts or Pennsylvania'. But Wilcox does not see the New South Wales jacket-gifts in this way. After all, 'it made little sense in Australia where frontier fighting was far smaller in scale', so the practice must have been merely 'an unthinking continuation of a tradition' ${ }^{50}$

Yet Phillip was embattled, and strategic gifting precisely is what was occurring on the shores of Sydney Harbour. Phillip could not control the movements of convicts, soldiers or sailors into Aboriginal country and they continued to be attacked, beaten and killed by Aboriginal warriors. Neither would he punish the warriors, even if he could, for his orders were to 'treat the natives kindly' and he had forbidden anyone from shooting or otherwise harming them. But fear, hatred and a longing for payback began to writhe among the convict populace. Phillip did not want a rebellion on his hands; but nor did he yet know much about the Eora - their numbers, their intentions. It was vital that a communication be opened so that the colonists could convey both their friendly, peaceable intentions - and their superior strength of arms. ${ }^{51}$

In Bennelong, then, the officers saw hope for peace between the two races, for they regarded him as a leader and a go-between, someone with whom they could negotiate, someone they hoped could control his people and stop the killings. The fine red jacket was a diplomatic tool in this process, a gift of esteem, an expression of hoped-for alliance and co-operation. As it turned out, their hopes were misplaced; and Bennelong seems to have understood and used the jacket in different ways altogether.

Shortly after that first reconciliation on the north shore, Bennelong and his people finally came into Sydney. The inclusion of Aboriginal people in the town had been official British policy as well as the genuine hope of Phillip and several of the officers from the start. ${ }^{52}$ Bennelong and Barangaroo were frequent visitors to Government House, and Bennelong always wore the favourite scarlet coat when he was in Sydney. As David Hansen points out, this kind of mimicry was not merely flattery of the Berewalgal leaders, but a customary form of respect. ${ }^{53}$ Again, just wearing it would have involved considerable effort and inconvenience, for it would have hung down to the back of his knees and felt heavy, hot, prickly. Whether Bennelong also wore it in Eora country away from Sydney is unknown, but it is possible that the red coat reinforced his meteoric rise in status among his own people, too. Bennelong had brokered this breakthrough with the Berewalgal, they were his new allies. He seemed to be very busy shoring up his position with the other Eora groups, the Kamaygal and Gweagal of Botany Bay and the powerful Cammeragal of Middle and North Harbours. ${ }^{54}$ Remembering the symbolic and visual power of the red coat, Bennelong's new jacket may have been a powerful asset in his ongoing negotiations with the other groups.

50 Wilcox 2009: 13, 15-16.

51 Karskens 2009: 361-371.

52 Tench 1979[1789/1793]: 53.

53 Hansen 2007: 27-32; Brad Manera, pers comm, 16 March 2011.

54 Tench 1979[1789/1793]: 200; Phillip, in Hunter 1968[1793]: 314, 315; Smith 2001: 68-69. 


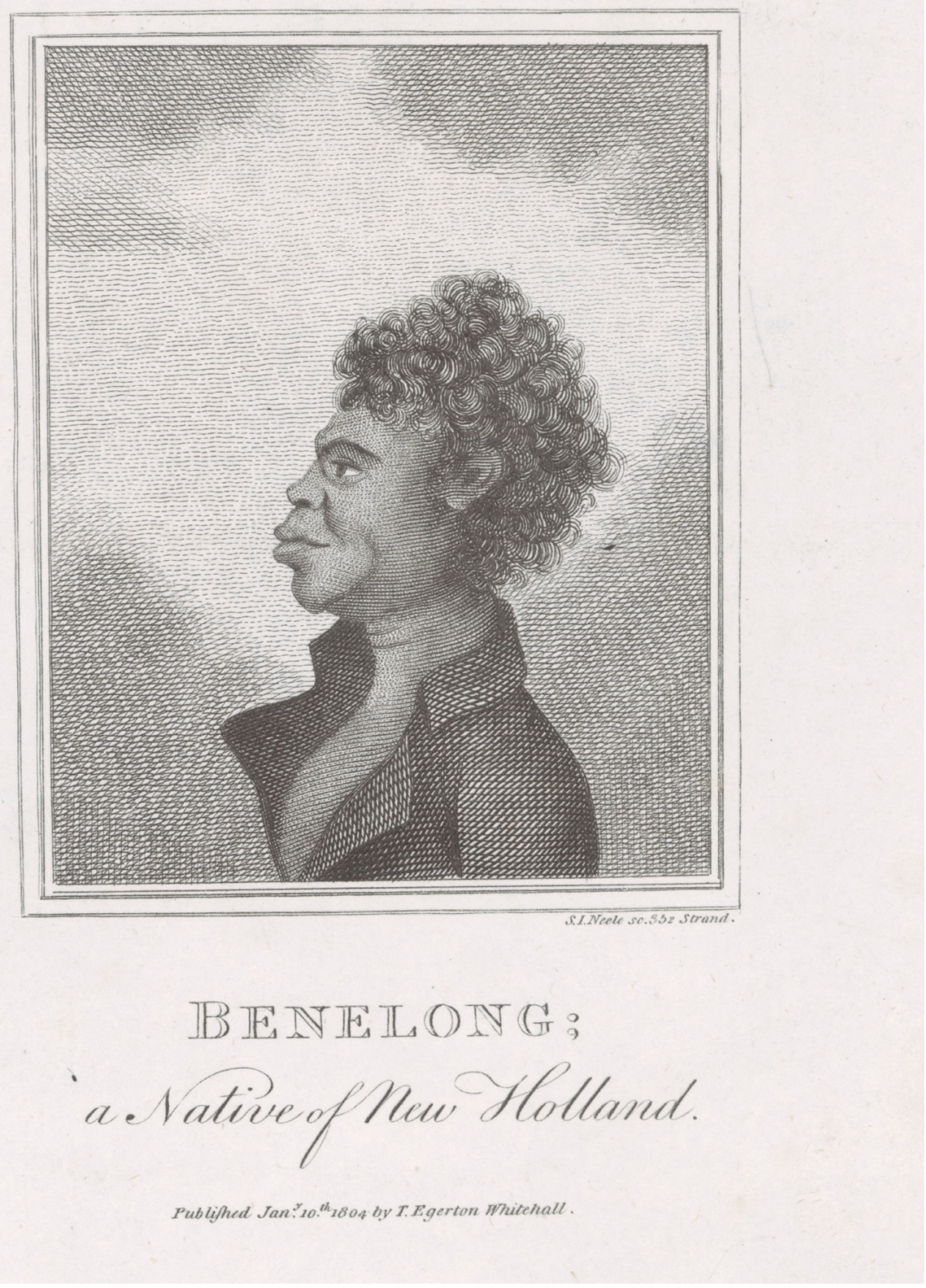

Fig 6. SJ Neele, 'Benelong a Native of New Holland', c1800.

Source: National Library of Australia, PIC S4297.

Bennelong was given many presents of clothing, but he often took garments with him when he left Sydney and returned without them. This was regarded by jealous white observers as evidence of savage, childish wastefulness, but it is likely he was using them as gifts or for trade. Nevertheless, he kept at least one 
other coat, for an early nineteenth century portrait shows him wearing a tailcoat (probably dark blue), the collar turned up - and without a shirt. ${ }^{55}$ It is possible, then, that the Aboriginal way of wearing jackets - straight over the skin, keeping the cicatrices on the chest visible - was established in the mid to late 1790s.

In the decades following, jacket-taking, gifting, trading and wearing continued, and can be glimpsed in places far from Sydney. These glimpses are rare and scattered, but I believe they represent a continued practice. The colony expanded relentlessly, first to Parramatta in 1790; then to the HawkesburyNepean River and its tributaries from 1794; and then to the southern regions around Campbelltown and Appin after 1809. The town of Sydney itself had not appropriated much land, and violent conflict there was limited to skirmishes and attacks on individuals or small groups who ventured into the areas around it. But when the Berewalgal began to take much larger areas of land for farms, they ignited a series of frontier wars. Aboriginal people resisted the invasion of their country, first at Prospect, then on the Hawkesbury (1795-c1809) and finally in the southern region (1814-1816). This was not a war with two distinct sides, though, for settlers also befriended Aboriginal people, giving them maize and clothing in the hope of continued good relations. Settlers also exploited the politics of tribal relations, forming alliances with some Aboriginal warriors against their enemies. ${ }^{56}$

War, friendship and revenge often twisted together on the frontier. In the foothills of the Blue Mountains in 1799, Aboriginal warriors killed two Hawkesbury settler men, Thomas Hoskisson and James Wimbow, while they were out on a hunting trip together. Hoskisson had always been on good terms with the Aboriginal people, but Wimbow had taken the daughter of one of the warriors to live with him. In retribution for their deaths, settlers at the Green Hills (later Windsor) killed two adolescent Aboriginal boys, Jemmy and Little George. These boys were well-known among the settlers, who had probably seen them grow up. The term 'boy', is misleading, for although they were only aged 16 or younger, they had been initiated and were therefore warriors. ${ }^{57}$

Before the killings three Aboriginal boys, including the two victims, had approached James Metcalfe as he worked on a farm, who invited them into the house. One of the boys, 'the biggest of the three' picked up Metcalfe's jacket, which was lying on the ground, and put it on before he followed the others into the house. It must have hung loose on the slim young frame, because once inside, he was seized, the coat was immediately pulled off, and a tomahawk was found hidden in the sleeve. What followed was a sort of rough trial, with more and more angry settlers arriving to interrogate the boys on the murders of the

55 Neele 1803.

56 Karskens 2009: chapters 5, 13.

57 Collins 1971[1798], 2: 281; R v Powell and others, 15-16 October 1799, in Minutes of Proceedings, Court of Criminal Judicature, State Records of NSW, X905: 323, 329-362. 
settler men. One boy escaped, but the other two were bound, taken to a barn, and shot and stabbed to death. Their bodies were later found, and the killers were arrested and tried for murder. ${ }^{58}$

Why did the oldest boy put the jacket on? The accused white men insisted it was to hide the weapon in the sleeve and therefore bespoke his violent intentions. But the boys, like all warriors, were openly armed anyway, with spears and womeras. These were also taken from them. Putting on the coat may have been a ritualistic gesture: to meet with white men, a warrior put on one of their coats, as a sign of...what? Politeness? A mimesis which was a 'customary form of respect' in this most urgent and dangerous of situations? An acknowledgement of the seriousness of the boys' predicament? The fact that it was Metcalf's coat suggests they were claiming a sort of allegiance with him. The boys clearly knew him well, and, indeed, he was the only one in the room that night who spoke up against killing them, while the rest bayed for blood. But neither Metcalfe nor his coat could protect them from the terrible act that followed, any more than Hoskisson's gifts to his Aboriginal friends had protected him. The coat was stripped off as soon as the boy entered the room, suggesting that the settlers, too, knew its meaning and intent, and would have none of it. It was as if the shared understandings, objects and rituals which had grown between the two groups had to be stripped away for this kind of frontier justice to be enacted.

Right from the start, the colony at Sydney Cove was a place of movement. Far from being a frightening alien 'gaol', the bush, waterways and coastlines constantly beckoned explorers, fortune-hunters, tourists and sightseers, escapees, foragers, fugitives and eventually cattle thieves and bushrangers. The latter, of course, are only vaguely glimpsed in official records; they are a kind of constant, murmuring 'underside' of colonial history. ${ }^{59}$

Their journeys also involved encounters and negotiations with Aboriginal people, and here too coats and jackets were objects of desire and trade. Settlers who went on exploratory journeys might find themselves jacketless through trading. One 1804 traveller 'in search of curiosity' walked to the Cowpastures, already a popular rambling and tourist destination, and found the Aboriginal people there (probably the Murringong) drove hard bargains. Desperate to possess a clutch of young emus, the traveller managed to talk the Aboriginal man out of demanding all his clothing in exchange for them. But the black man would not budge on the jacket, despite the white man's protestations that he would 'fall victim to the extreme coldness of the night'. That 'objection he effectually silenced by demanding, What for I should be colder when I had parted with my jacket than he himself was that never had one?'. 'This argument was unanswerable' wrote the flummoxed traveller 'and as I did not choose to part with the birds, I was necessitated to deal for them in his own way'. ${ }^{60}$

58 R v Powell and others, 15-16 October 1799, in Minutes of Proceedings, Court of Criminal Judicature, State Records of NSW, X905.

59 Karskens 2009: chapter 9, 356ff.

60 Sydney Gazette, 23 September 1804. 
It was September, so the locals had just emerged from the winter months, when temperatures can fall below $0^{\circ}$ Celsius. Here, then, one reason for demanding jackets may well have been practical - for warmth and protection - in the same way that certain other useful European artefacts were readily adopted: steel axes and fishhooks, for example, and glass, which could be fashioned into sharp blades, scrapers and spear points.

Even as far away as Jervis Bay, 150 kilometres south of Sydney, Aboriginal men sought jackets. In October 1805, a group of sealers led by ex-convict Joseph Murrell landed in Jervis Bay to collect water for a voyage to King Island in Bass Strait. They were attacked by hostile warriors, Murrell was speared in the back and the crew retreated to nearby Bowen Island. There a seemingly more friendly group visited them, and 'begged a jacket or two'. They promised to bring fish, and left 'four boys as hostage' with Murrell's group. But perhaps the voyagers in fact took these boys by force, because 'these wretches soon returned accompanied by a vast number of others armed in their canoes'. A battle of muskets and spears ensued, two warriors were killed and several more wounded. A third attack saw the voyagers depart speedily in their whaleboat, leaving their provisions and necessaries - and presumably jackets - behind. ${ }^{61}$

Clearly, the demand for jackets had spread far from Sydney. But why did the warriors of Jervis Bay want them? For warmth? For meeting with the strangers? Either way they continued to be key items in the constellation of things which crossed over in what Philip Jones calls the frontier zone: that edgy, dangerous, unpredictable place. In 1809 the crew of the vessel Hawkesbury were similarly attacked at isolated Mangrove Point on the lower Hawkesbury River. Armed men clambered aboard as they were sleeping. They responded with musket fire, killing at least two warriors. Still the people on the shoreline tried to get them to land, and 'exposed a jacket with some other articles they had stolen, at the same time inviting one of the people to come for them'. The white men thought it a ruse, a deadly lure. Or was it a desperate attempt to make peace, stop further killings? Either way, this jacket had been acquired in what was then still Aboriginal country, isolated from towns and settlers. It was clearly considered a valuable object, a bargaining tool, something which might serve an important purpose.

Aboriginal men closer to the urban areas also continued to take jackets from carts or boats where the whites left them. ${ }^{62}$ The garments disappeared along the trade or exchange networks; at other times they were worn by the thief himself. Jackets appear to have been adopted as the customary dress of resistance fighters. The warrior Tedbury, son of the famous resistance warrior Pemulwuy, was arrested at Pennant Hills in 1805 after a series of attacks and raids on settlers in the region. Marched under guard back to Parramatta, he nearly escaped by

61 Sydney Gazette, 27 October 1805; see also 3 November 1805.

62 Sydney Gazette, 30 December 1804, 3 June 1815. 
'flipping his jacket' and slipping away. ${ }^{63}$ I suspect that the Aboriginal gangs who bailed up travellers on the Parramatta Road with the same swagger and defiance as white bushrangers were wearing jackets too.

Aboriginal people have lived in Sydney ever since Bennelong, his family and friends 'came in' in late 1790. They came out of curiosity, having heard the stories about the town which moved like wildfire across the country. They joined Aboriginal people already living there, drawn by the great resources of food and drink that Sydney offered, and by the great contests and corroborees held in the town. They camped in the bushland encircling the town, or on the north shore. Some probably came to be close to children who went, or were taken, to live in the white people's houses. ${ }^{64}$

It is worth remembering what the British originally expected Aboriginal people to do when they settled down in town among the whites, since these expectations shaped the way they described them. They envisaged the Eora living harmoniously among them, living in proper houses, speaking English, cooking and eating English-style food, exercising public decorum and of course wearing clothes. As for economic use, the British thought that Aborigines might make quite a 'serviceable people', performing the lowliest and hardest labour, tending stock, sailing boats, drawing water and hewing wood. Officially Aboriginal people were British subjects, bound and protected by British laws, though in practice they had no such rights or responsibilities. ${ }^{65}$

What is striking about the earliest urban Aboriginal people is the way they so quickly forged new lives among the invaders in the growing port town, in ways which were nonetheless compatible with their customary habits and laws. They still camped in the open in the bushland that surrounded the town, or sheltered in traditional bark and timber gunyahs. They continued to eat familiar foods shellfish and fish cooked quickly over a fire - but also adopted maize and bread, and the pleasures of alcohol and tobacco. Fishing provided most of their income, for they found a ready market for fresh fish and oysters among the townsfolk and they also mastered European-style fishing boats. From the earliest years, too, Eora men in particular made deliberate, almost hyper-masculine, claims to urban space through their initiation rituals, fights and the great contests which enforced Aboriginal Law. Aboriginal urban geography thus overlaid the white one, and of all these places, the great contest ground at the south end of Hyde Park (now the site of the Sydney Anzac Memorial) was pre-eminent. ${ }^{66}$

As for clothing, during the first decade of the nineteenth century, most observers reported that Aboriginal people in Sydney continued to go about the

63 Sydney Gazette, 19 May 1805.

64 Karskens 2009: chapter 12.

65 Collins 1971[1798], 1: 543; Tench 1979[1789/1793]: 239; Phillip, in Hunter 1968[1793]: 352.

66 Karskens 2009: 431-446. 
town unclothed, and artists depicted them that way too. ${ }^{67}$ Old colonists were apparently completely accustomed to this, though newcomers were invariably shocked. 'I met a native today', gentleman convict John Grant told his mother in 1804, 'a tall, black, stark naked Man! By Job, it startled me at first, for the fellow turned a corner suddenly near me, in the town' ${ }^{68}$ Settler-on-the-make Christiana Brooks spluttered that it was 'disgraceful to a town such as Sydney to meet natives of both sexes entirely naked' ${ }^{69}$ Even in the 1820s they appear in some images unclothed, and some Aborigines worked that way as well. A visiting Russian captain reflected mildly that 'one soon gets accustomed to looking at them, and does so without disgust'..$^{70}$ Evidently it was the Europeans who had to adjust, not the other way around.

By the late 1810s, though, Aboriginal people always asked their visitors for clothing, and jackets and coats had become the dress of choice among Aboriginal men living in or visiting Sydney - those who chose to wear anything at all. They wore the garments in distinctive ways. In contrast to the fashionable tight-fitting jackets and slim pants of the higher ranks of white men, and the soldiers' closecut red coats, the warriors' jackets were ill-fitting - sometimes too tight, but more often loose-fitting and worn unbuttoned, without trousers or shirt. The looser fit would have been more comfortable to people who normally went unclothed; free movement was essential for hunting, fighting, hurling spears or defending oneself. The too-tight fit - buttons straining across chests, cloth straining under arms - suggests that wearing the jacket was considered necessary, even if uncomfortable: a jacket that was too small was better than none. The unbuttoned coat would also leave the all-important cicatrices visible, while absent trousers could leave no doubts about gender.

Jacketed warriors were often portrayed with the spears they always carried. One jacketed man in Earle's lithograph 'Natives of N. S. Wales as seen on the streets of Sydney' carries a traditional club - a waddy. Others added additional small items of dress. Jedat, a warrior from the Nepean River, wears a red head scarf (with a clay pipe tucked jauntily into it), together with a cascade of kangaroo teeth on his chest. Bungaree customarily wore a clay-daubed plaited headband with his jackets, as well as the engraved gorget presented to him by Governor Macquarie. ${ }^{71}$

67 See Evans c1808, 'New South Wales, View of Sydney from the West side of the Cove No 1', watercolour, Mitchell Library; Lewin 1808, 'Australian and his wife', pencil sketch, Mitchell Library; Eyre c1808.

68 Grant 2000[1804]: 38.

69 Brooks cited in Maynard 1994: 64.

70 Bellingshausen 1981[1820]: 43; see Carmichael 1829a, b, 'George Street from the wharf' and 'Sydney from the Parramatta Road', intaglio engravings, National Gallery of Australia.

71 Freycinet 2001[1824]: plates opp 124, 306; Pellion 1819a, 'Sauvages de la Nouvelle Galles du Sud (d'apre nature dans leur Camp pres de Sidney (20 dec. 1819)', watercolour, Mitchell Library; Pellion 1819b, Drawings and etchings of Nepean and Springwood Aboriginal men by and after Alphonse Pellion, Mitchell Library; Earle c1830, 'Natives of N. S. Wales as seen in the streets of Sydney', lithograph, National Library of Australia; Le Jeune 1824; Mikhailov 1820, Sketches of Aboriginal people, in album of photographs of drawings and watercolours in the State Russian Museum, Leningrad, copies held in National Library of Australia; Artist unknown c1838, 'Real Life in Sydney', lithograph, Mitchell Library. 
Many of the coats were indeed military coats. The symbolic prestige and power they held in the contact period appears to have continued. In Pellion's 1819 sketch of the men from the Nepean, Tara wears a double breasted civilian tailcoat in dark blue wool, a garment commonly worn as undress by military personnel. Peroa, standing side on, wears a sleeved military waistcoat made of unbleached wool with yellow facings which had probably belonged to a soldier of the 46th regiment (the South Devons). These were the items of 'undress' that the soldiers wore for ordinary duties. The regiment was in Sydney between 1814 and 1817, so this jacket was not a discontinued item, but current issue uniform. Peroa must have acquired it relatively recently when the sketch was made.

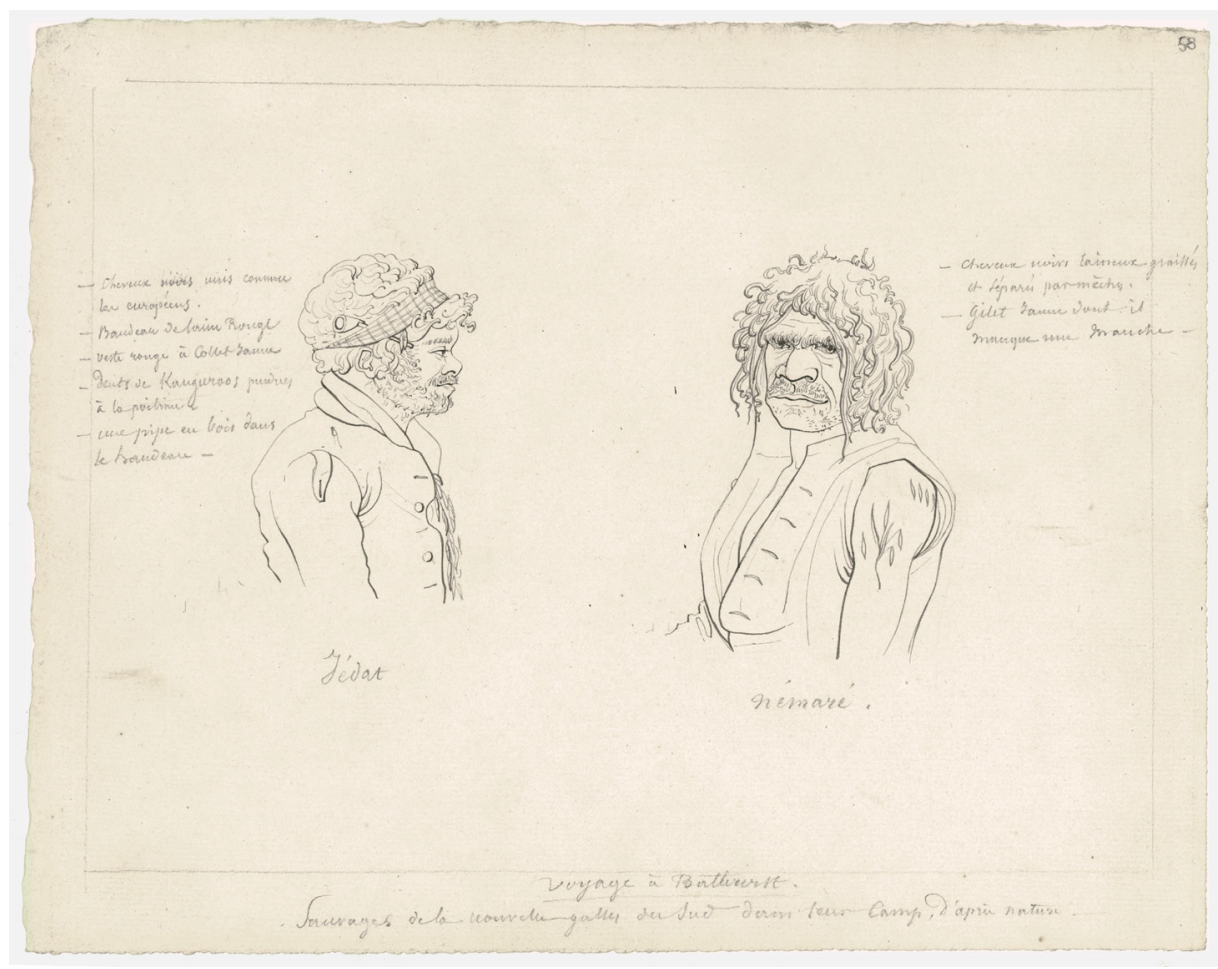

Fig 7. Alphonse Pellion, 'Jedat et Nemare', pencil sketch, 1819.

Source: Mitchell Library, State Library of New South Wales, PXD 923/2.

Pellion's other sketches and notes were later transformed into an engraved composite image showing Nepean men Jedat, Tara and Nemare from the waist up. Jedat (with bandana and pipe) sports a red officer's coatee with yellow facings. These garments, introduced around 1790, were much lighter, shorter and more comfortable than the coats that Bennelong and Coleby had worn two decades before. Jedat's coatee could have also have originated with the South Devonshires, or it might have come from the New South Wales Corps. Tara appears again in his blue tailcoat, though one sleeve is shown 'torn off' with 
artificial jaggedness by the artist. Meanwhile Nemare wears a convict-issue yellow waistcoat, which would have been a more comfortable option. His hair is dreadlocked and the cicatrices are clearly visible on his upper arm. ${ }^{72}$

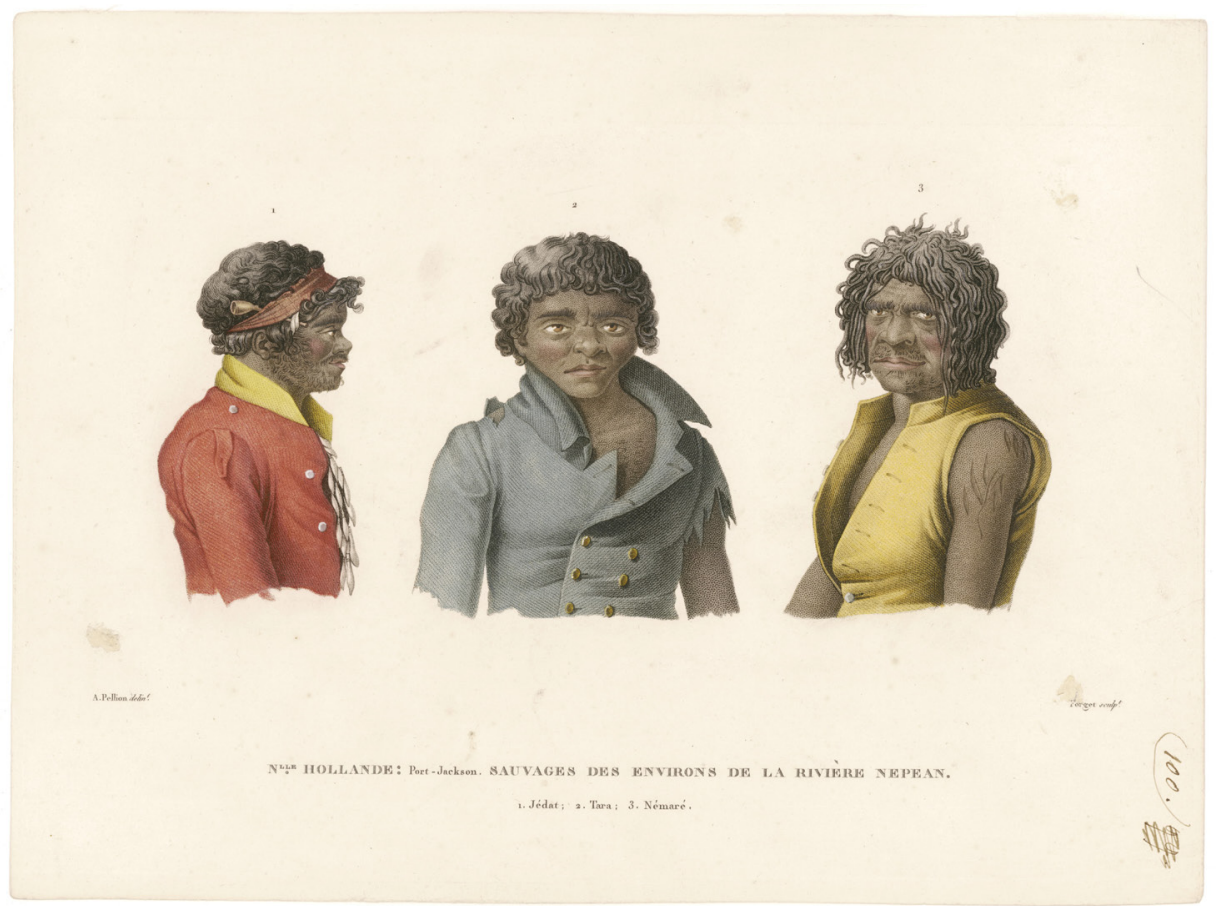

Fig 8. E Forget, 'Nouvelle-Holland, Port Jackson, Sauvages des environs de la Riviere Nepean', print, based on sketches by Alphonse Peron, Paris c1822.

Source: Mitchell Library, State Library of New South Wales, PXD923/5.

One of the coats shown in Augustus Earle's 1830 tableau 'Natives of N. S. Wales as seen on the streets of Sydney' is also identifiable: the man with the waddy standing with his back to the artist wears an officer's coatee. This one is red with buff facings, the little tails nattily turned up to reveal the buff. It originated either with the 48th Regiment - in New South Wales between 1817 and 1824 - or the 3rd Regiment, three detachments of which were in Sydney from 1823 to 1827 , the same time Earle was visiting. The fact that warriors were wearing officers' coats is significant. While soldiers were forbidden to sell or give away their uniforms, officers purchased their own, and were thus free to gift or trade them. It is possible that warriors had personal links with the officers from whom they acquired their jackets, in the same way that warriors in the early contact period had exchanged names with officers, and were known by these European names long after their namesakes had departed. ${ }^{73}$

72 Brad Manera, pers comm, 11 April 2011.

73 Brad Manera, pers comm, 11 April 2011; Sydney Gazette, 15 January 1809; Smith 2007: 22, 93, 100. 


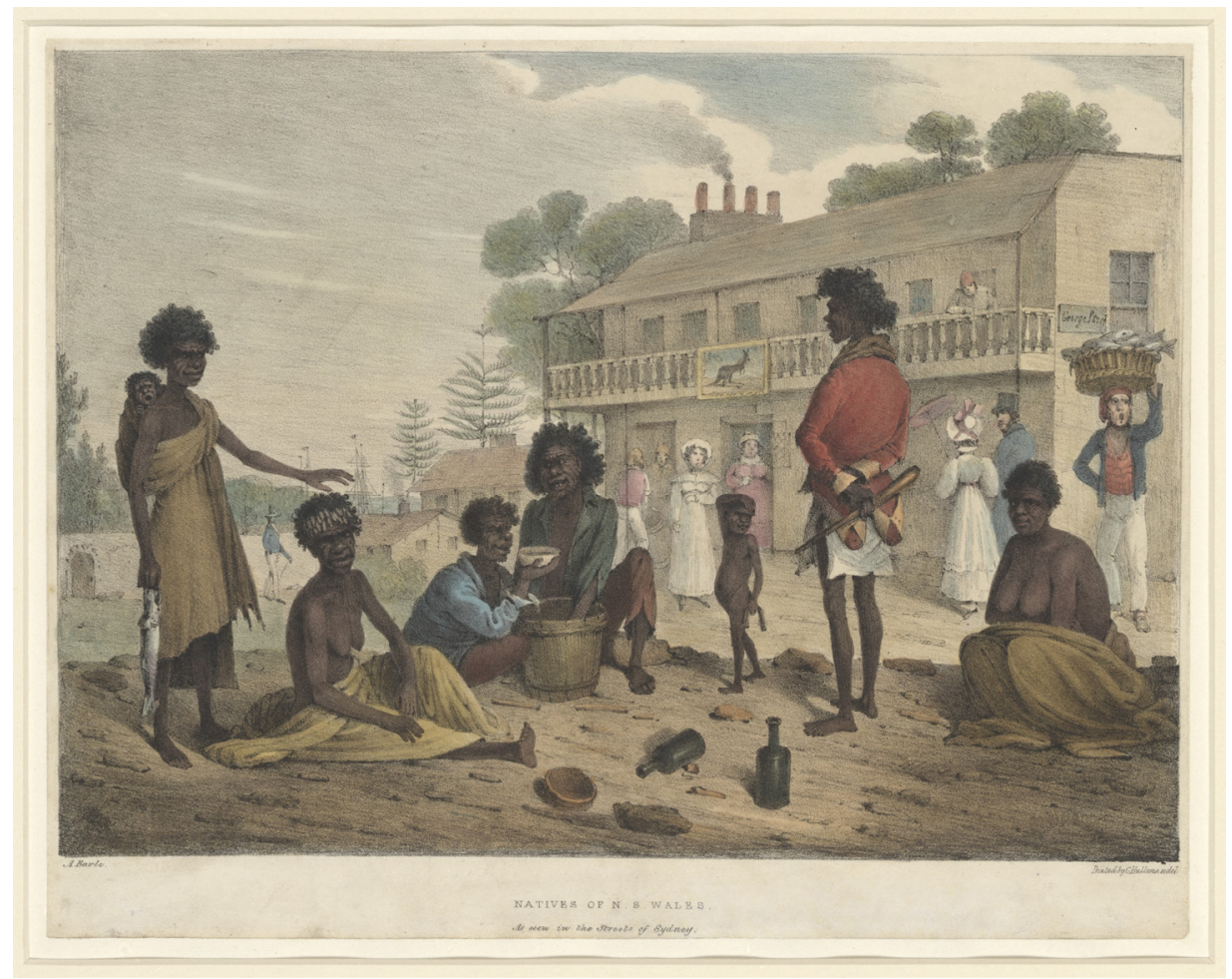

Fig 9. Augustus Earle, 'Natives of N. S. Wales as seen in the streets of Sydney', c1826.

Source: National Library of Australia, NK1239/3.

A close comparison of Earle's picture, itself made up of separate sketches, and the anonymous lithograph 'Real Life in Sydney', reveals the extent to which these images were recycled, manipulated and rendered increasingly grotesque in the 1830s. The man in the coat reappears in the same garment, tails and all, but is now depicted in a fight. The women no longer carry fish but drink from the black glass bottles. The same child appears, in the same pose, his belly horribly distended. The other figures are wearing the convict, naval or military front fall trousers and slop shirts of two decades earlier.

Bungaree's famous red coat - very likely the one given to him by Macquarie in 1822 just before the Governor left the colony - signalled his status as leader and representative of his people, at least to the Europeans. It was the uniform of a Brigadier General, or a general's Aide-de-Camp, though the elaborate epaulettes are missing. Fascinatingly, in Earle's portrait, Bungaree wears the coat it as it would have been worn by a general on parade, with the front buttoned back to reveal the dark facing, rather than simply buttoned up. This would have involved a complicated set of hooks and eyes, and considerable time and trouble. 
Bungaree also wears the correct bi-corne hat and sash for this uniform, though the hat is missing its feather hackle. The baggy, ragged slop trousers he wears are thus a striking contrast to the careful correctness of the uniform. ${ }^{74}$

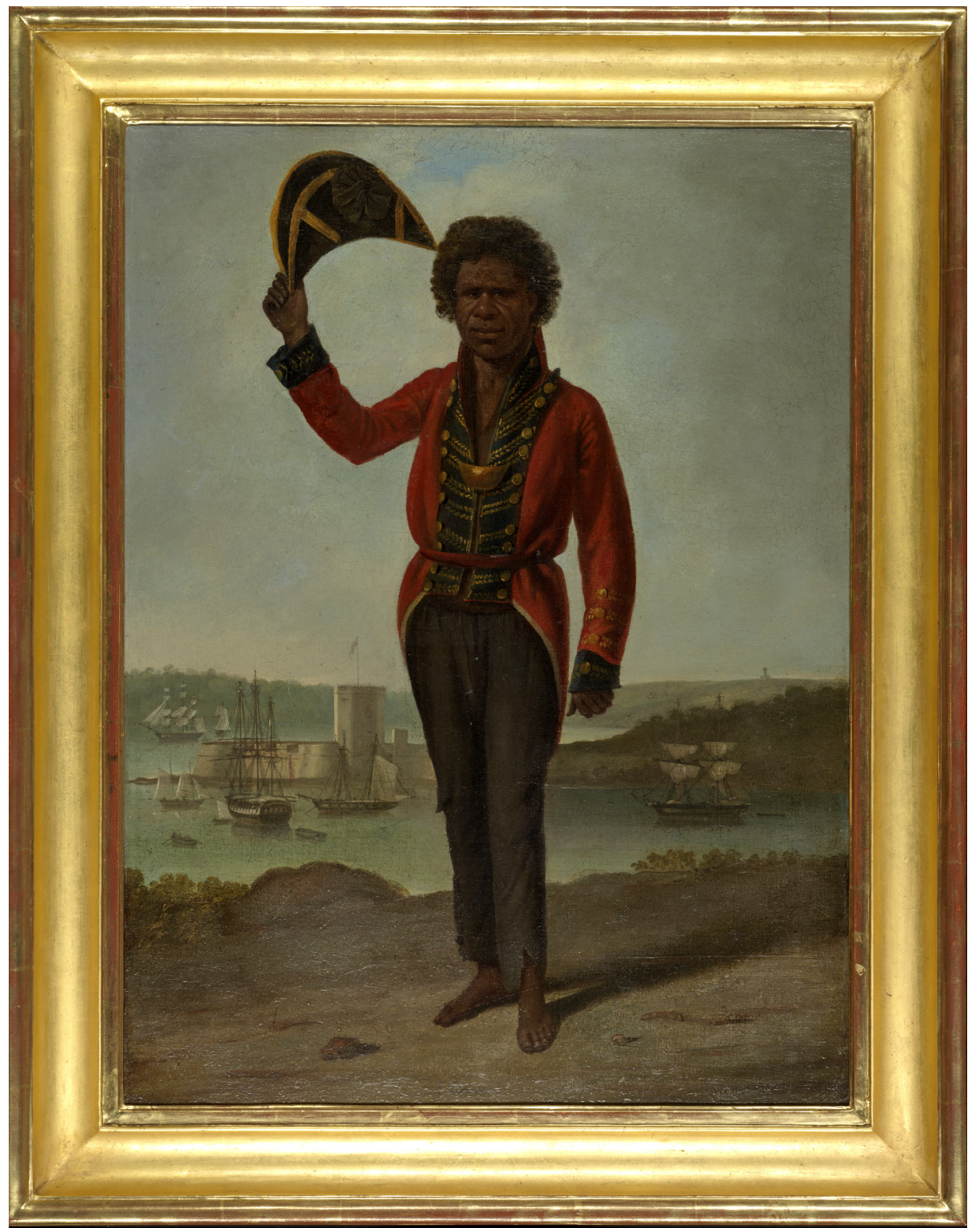

Fig 10. Augustus Earle, 'Portrait of Bungaree, a native of New South Wales', c1826.

Source: National Library of Australia, NK118.

74 Brad Manera, pers comm, 11 April 2011. 
But Macquarie's coat was no strategic gift, as Phillip's had been to Bennelong. Macquarie believed that the war between Aborigines and settlers was over, and that a permanent peace had been established. He wrote that he gave Bungaree his own old uniform 'to dress him out as chief'. It was a genuine, very personal parting gift, bespeaking friendship and farewell, but it also reflects the viceregal couple's taste for the fashionably exotic, their love of the visual. Bungaree was the Macquaries' friend and 'favourite', so perhaps there was an element of 'dressing him up' in the general's coat, for visual effect, an eye-catching spectacle of reversal: the striking red coat on the black skin, the symbol of prestige and power on the body of a native man. ${ }^{75}$

Bungaree's own personal flamboyance and taste combined spectacularly with his role as welcomer of ships, go-between, peacemaker and elder, and his public persona in Sydney (in 1829 the Sydney Gazette declared firmly that 'Boongaree is identified with Sydney'). ${ }^{76}$ The red coat became almost inseparable from the man himself, an object of mystique and meditation. Yet Bungaree had a much larger wardrobe of coats and elaborate hats, including a Russian great coat with frogs, a drab brown suit, a bright blue dress coat with gold frogs and loops, a full dress naval uniform, and a canary yellow convict suit, and he wore them all at different times. ${ }^{77}$

So red coats and other military garb very likely continued to command attention, and carry status. They offered, too, the beauty of cut, colour and embellishment, and possibly they also represented the bonds of friendship. ${ }^{78}$ But the warriors did not shun the humbler garments - the stigma of yellow convict clothing, for example, did not necessarily cross over into Aboriginal culture, as seen demonstrated in the case of Nemare and his waistcoat. Bungaree was seen in his yellow suit, too, and the warriors also begged, bartered or stole the humble blue gurrah convict's or labourer's jackets. Again, it seems that having access to a jacket or coat was more important than what type it was. Perhaps the humbler garments were approximations and substitutes for the military jackets.

Most telling of all is the way the warriors so easily shucked the jackets off when back at their own camps, or for corroborees and contests. When Bungaree visited Frenchman Rene Lesson in 1822 on his way to corroborees and contests, he appeared a transformed man. The coat and plumed hat were gone, his powerful body was dusted with red ochre and painted with red and white clay, his canoe filled with spears and clubs. ${ }^{79}$ The warriors moved easily back and forth between white and Aboriginal worlds, and they had made the white world partly their own.

75 Macquarie 1822: entry 11 February ; Wilcox 2009: 21.

76 Sydney Gazette, 9 July 1829.

77 Smith 1992: 153.

78 Wilcox 2009: 20-21.

79 Lesson, cited in Smith 1992: 128-129. 


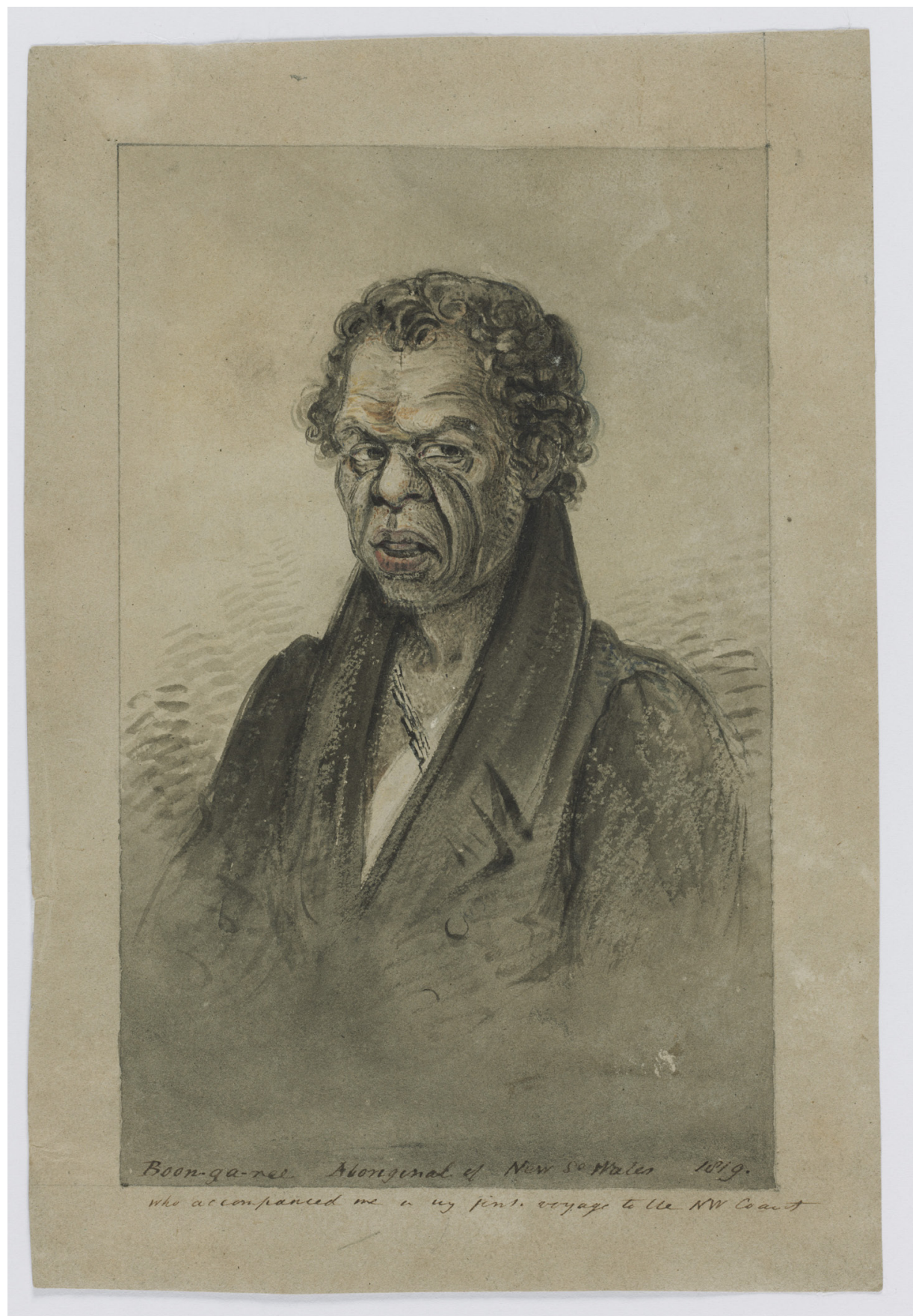

Fig 11. Phillip Parker King, 'Boon-ga-ree aboriginal of new St Wales 1819 who accompanied me on my first voyage to the N W coast', 1819.

Source: Mitchell Library, State Library of New South Wales, PXC767. 
To the Europeans, the warriors seemed to be deliberately subverting the purposes of modesty and propriety. Wearing clothes was considered a key sign of the 'civilisation' process in action, for it was assumed that simply being in the presence of clothed white people would open Aboriginal eyes to their own 'nakedness', awaken a sense of shame, and teach them modesty. But after 40 years, some Aboriginal people still customarily went unclothed. Women wore blankets wrapped around them like togas, or like mantles, with holes cut in the middle, while the men wore jackets in ways that caused consternation, for 'they especially hate clothes for the lower part of the body'. Lesson spluttered in 1822: 'The stubbornness of this race in rejecting even the narrow loincloth would deeply astonish the moralist'. (Jacques Arago added highly improbable loincloths to his even more improbable pictures of Aboriginal men.) Despite the obvious and rather radical adaptation involved in wearing jackets (not to mention shaving, adopting metal hatchets, eating new foods and adapting to town life), another French visitor, Hyacinthe De Bougainville wrote in 1825 'they have remained absolutely the same since the Europeans set foot here' ${ }^{80}$

There were some Aboriginal men who wore trousers: the sailors. Since 1791 they had joined crews on the coastal, sealing and international voyages, and adopted the 'wide trousers, round jackets and straw hats' of sailors. Despite their contribution to early trade and exploration, and their trousers, they too were condemned. Louis de Freycinet decided that he could not count them as 'civilised natives' because they 'have been so degraded by the intemperate use of strong liquor that they are not of much use to anybody' ${ }^{81}$

The other common response was ridicule, sometimes mingled with horror and disgust, or pity for these poor creatures, who could not know how to wear clothes properly, and seemed to be the victims of cruel hoaxes. The less-thanenchanted Lesson described Bungaree's

Bowing and scraping, his grotesque way of dressing made him look even more ridiculous. He wore an old dragoon's helmet, and around his chest flapped a toggled greatcoat left to him by the last Russian expedition' ${ }^{82}$

Surgeon Peter Cunningham amusingly contrasted Bungaree's 'gold-laced blue coat' with his 'bare and broad platter feet'. ${ }^{83}$

The Russian visitors on the ships Vostok and Mirnyy arrived in 1820 expecting to see the natives of New South Wales unclothed. But when Bungaree's welcoming party boarded the ship, Captain Bellingshausen could find no proper way to describe them. He wrote of Bungaree's trousers, headband and breastplate, his wife Matora's blanket, and the kangaroo teeth in her hair. And yet he wrote: 'all were naked'. ${ }^{44}$ Their artist Pavel Mikhailov made beautiful sketches of Bungaree,

80 Lesson (1822) and Bougainville (1825), cited in Dyer 2005: 189, 196, 180; see Arago 1971[1823].

81 de Bougainville 1999[1825]: 174; Freycinet 2001[1824]: 300.

82 Lesson, cited in Dyer 2005: 181.

83 Cunningham 1966[1827]: 74.

84 Bellingshausen 1981[1820]: 34. 
Matora and the sailors Mahroot and Salamander, but he must have asked them to remove their clothing, so he could depict them in their 'proper' native state. ${ }^{85}$ Here it becomes clear that clothing was associated with 'the corruption, the debasement, the brutality and the profligacy which was introduced among them' ${ }^{86}$ 'Nakedness' bespoke savage life: wild and primitive, but at least pure, unspoiled and 'genuine'. Perhaps most disturbing to unaccustomed white eyes was the Aboriginal combination of dress and undress, this tatterdemalion upending of every expectation. They were the same 'dreadful sort of half-world clothes' from which Kerr and Kirby recoiled a century and a half later.

Pity, revulsion, annoyance, laughter, unease, a taste for the exotic: these were the responses of visiting Europeans to Aboriginal jacket-wearing, the lenses through which they saw them. These lenses offer insights into the way longstanding 'conventions of perception' shaped the Europeans' view, and the pictures and texts they made. But what do the longer view, the 'moment of exchange', and the wider social and cultural contexts, suggest about the jackets from an Aboriginal perspective? What are the 'interpretative possibilities'? Clearly, they were desired by Aboriginal men from the early years, the practice spread quickly into the vaster Aboriginal hinterland, and the garments were steadily acquired through gift, trade or theft. The glimpses available suggest that this practice cannot be explained as empty mimicry, by European coercion, or as signs of impoverishment and culture loss. They suggest a 'third way' of seeing, one which moves beyond the binary of pure, unchanging savage/corrupted outcast. They suggest a syncretic culture, and hidden dynamics of contact, negotiation and concession which reach back to the earliest years of colonisation. ${ }^{87}$

David Hansen, in his fine meditation on Earle's portrait of Bungaree, wrote of the meanings of Aboriginal mimesis as 'the adoption of new gestures to permit the maintenance of Aboriginal protocols of meeting under the new regime'. He focused on the 'dance of encounter' in which Aborigines quickly mimed the movements of the strangers in a 'ritual physical performance ... to neutralise the charged, uncertain and dangerous space of the meeting' ${ }^{88}$ Jacket-wearing may represent an early example of these new protocols, this mimetic strategy of 'dancing between the very same and the very different' ${ }^{89}$ In this scenario, coats and jackets were sought after so that black men, particularly younger men, could meet white men with the proper rituals and gestures in those 'charged spaces'. It was a way of neutralising the power of the Europeans, with their deadly geerubber (muskets), of making the strange familiar, a gesture proclaiming: we

85 Mikhailov 1820, Sketches of Aboriginal people, in album of photographs of drawings and watercolours in the State Russian Museum, Leningrad, copies held in National Library of Australia.

86 Govett 1836: 202.

87 Rowse 1991: 5; Thomas 1999: 43-46.

88 Hansen 2007: 32.

89 Taussig 1993: 129. 
too are men, and warriors, we can match you, but we do it our way. Perhaps it was also, as Anna Cole perceptively writes, 'a process of copying or imitating something in order to change yourself as well as the thing you imitate'.$^{90}$

Warriors of particular renown, like Bennelong, may have inspired young, newlyinitiated boys to copy them. And while some jackets were traded, begged or stolen, others signified links with their original owners: Bennelong with Phillip and Collins; the Aboriginal boy with the settler James Metcalf. Bungaree's wardrobe represented his links not only with Governor Macquarie but the many ships' captains and visitors he welcomed into Sydney.

Most obvious is the profoundly gendered nature of the practice. Although there were attempts by women to acquire jackets very early in the contact period, and even though jackets were ordered for them well into the 1810s, jacket-wearing appears to have been commandeered exclusively by men. This may well have been prompted and encouraged by the way European men dealt officially and diplomatically only with Aboriginal men. After the smallpox epidemic of 1789 especially, young, often aggressive men dominated cross-cultural relations, partly because the disease appears to have killed a disproportionate number of older people, and women, but also because Governor Phillip and the officers deliberately dealt with younger warriors in their twenties and thirties, rather than the old men who had earlier controlled all the meetings. ${ }^{91}$

In Sydney the jackets, along with metal hatchet, clipped beards, or shaved or stubbly faces, marked out warriors in the post-invasion, post smallpox era. They may have signified male status in a new order, as well as a continuation of the old order, which Inga Clendinnen aptly calls a 'tough warrior culture'. We might link them with the determined efforts to create masculine ceremonial and ritual spaces within the early town. Jackets may also have been a means by which Aboriginal men could signify gender identification with white men - the most significant concern from the beginning - and rough alliances, not as ciphers to do their bidding, but as men meeting on equal terms to negotiate over power and authority, over hunting and travelling, over goods - and over women.

The fact that both jacket-wearing and being unclothed were customary also suggests that personal, group or cultural choices were being made according to circumstance. Here the possibilities are multiplied by what we do not, and perhaps cannot, know. We 'see' warriors wearing jackets when in town, and/ or in the company of whites, but observers suggested that they were shucked off back at the camps. Bungaree, like the Arrernte decades later, wore clothes for meetings with whites, and in the streets of the town, but took them off for ceremonies and contests. ${ }^{92}$ Did jacket-wearing have any meaning outside the towns, far from the farms and roads, away from the white people? Perhaps future researchers will glimpse them, lying around the campsites, buttons glinting in

90 Cole 2010: 215.

91 Karskens 2009: 372-378.

92 See footnote 76; Brock 2007: 11-12. 
the firelight. But then it will be necessary to re-imagine the vaster Aboriginal world, as Tiffany Shellam has done in her study of the King Ya-nup of King George's Sound in Western Australia, a world in which the goings on at Sydney Cove might well have been only one small aspect of Aboriginal relations and politics. ${ }^{93}$

\section{References}

\section{Primary sources}

Artist unknown c1838, 'Real Life in Sydney', lithograph, Mitchell Library, Sydney.

Arago, Jacques 1971[1823], Narrative of a Voyage Around the World, N. Israel, Amsterdam/De Capo Press, New York.

Bellingshausen, Captain FG, Journal, March-April 1820, in Glynn Barratt 1981, The Russians in Port Jackson 1814-1822, Australian Institute of Aboriginal Studies, Canberra: 34-46.

Bradley, William, Journal: A Voyage to New South Wales, December 1786 - May 1792, compiled 1803, Mitchell Library, Sydney.

Carmichael, John 1826, 'King of Black Natives', watercolour and ink, Mitchell Library, Sydney.

- 1829a, 'George Street from the wharf', intaglio engraving, National Gallery of Australia, Canberra.

- 1829b, 'Sydney from the Parramatta Road', intaglio engraving, National Library of Australia, Canberra.

Clark, Ralph, letter to Lt. William Collins, 1 October 1788, Letterbook, Mitchell Library, Sydney.

Collins, David 1971[1798], An Account of the English Colony in New South Wales, 2 volumes, facs ed, Libraries Board of South Australia, Adelaide.

Cunningham, Peter 1966[1827], Two Years in New South Wales, DS MacMillan (ed), Angus \& Robertson, Sydney.

de Bougainville, Hyacinthe 1999[1825], The Governor's Noble Guest: Hyacinthe de Bougainville's account of Port Jackson, 1825, Marc Serge Riviere (trans and ed), Miegunyah Press, Melbourne.

93 Shellam 2009. 
de Freycinet, Louis 2001[1824], Reflections on New South Wales, Hordern House, Sydney.

Earle, Augustus c1826, 'A native family of New South Wales sitting down on English settlers farm', watercolour, National Library of Australia, Canberra.

- c1830, 'Natives of N. S. Wales as seen in the streets of Sydney', lithograph, National Library of Australia, Canberra.

Evans, George (attrib.) 1803, 'Sydney from the West side of the Cove', watercolour, Mitchell Library, Sydney.

Eyre, John c1808, 'New South Wales, View of Sydney from the West side of the Cove No 1', watercolour, Mitchell Library, Sydney.

Fernyhough, WH c1836, 'A series of twelve profile portraits of Aborigines of New South Wales, drawn from life and on stone', silhouettes, National Library of Australia, Canberra.

- 1840, 'Natives of NSW drinking Bull', silhouette, National Library of Australia, Canberra.

Gill, ST 1866, 'Native Dignity', lithograph, National Gallery of Australia, Canberra.

Govett, William Romaine 1836, 'Sketches of New South Wales', The Saturday Magazine, VIII.

Grant, John 2000[1803-1810], This Beauteous, Wicked Place: Letters and Journals of John Grant, Gentleman Convict, Yvonne Cramer (ed), National Library of Australia, Canberra.

Hunter, John 1968[1793], An Historical Journal of Events at Sydney and at Sea 17871792, Angus and Robertson, Sydney.

King, Philip Gidley, Private Journal, vol 1, 24 October 1786 - 12 January 1789, Mitchell Library, Sydney.

- Fair copy of 'Remarks \& Journal kept on the Expedition to form a Colony ...', 1786 - December 1790; compiled 1790, Mitchell Library, Sydney.

Le Jeune, Jules-Louis 1824, 'Indigenos de nouvelle hollande', pen and ink sketch reproduced in Smith, KV 1992, King Bungaree: 128.

Lewin, John 1808, 'Australian and his wife', pencil sketch, Mitchell Library, Sydney.

Macquarie, Lachlan 1822, Journal, Mitchell Library, Sydney. 
Mason, Walter G 1857, 'Public meeting at Macquarie Place, Sydney, during the election', print, wood engraving, National Library of Australia, Canberra.

Mikhailov, Pavel 1820, Sketches of Aboriginal people, in album of photographs of drawings and watercolours in the State Russian Museum, Leningrad, copies held in National Library of Australia, Canberra.

Neele, SJ 1803, 'Benelong A Native of New Holland', published in James Grant, The narrative of a voyage of discovery, performed in His Majesty's vessel the Lady Nelson...1800, 1801 and 1802, to New South Wales, T. Egerton, London.

Nicholas, William 1840-42, 'Profiles of the Aborigines of New South Wales 18401842 ', silhouettes, National Library of Australia, Canberra.

Pellion, Alphonse 1819a, 'Sauvages de la Nouvelle Galles du Sud (d'apre nature dans leur Camp pres de Sidney (20 dec. 1819)', watercolour, Mitchell Library, Sydney.

- 1819b, Drawings and etchings of Nepean and Springwood Aboriginal men by and after Alphonse Pellion, Mitchell Library, Sydney.

Phelps, PHF 1840, 'Native Scenes', pen and ink drawings, Mitchell Library, Sydney.

Quoy, Rene Constant, Charles Gaudichaud and Alphonse Pellion 1950[1819], 'Excursion to the Town of Bathurst, 1819', in Fourteen Journeys over the Blue Mountains of New South Wales 1813-1841, George Mackaness (ed), Australian Historical Monographs, Sydney: 7-12.

R v Powell and others, 15-16 October 1799, in Minutes of Proceedings, Court of Criminal Judicature, State Records of NSW, X905: 323, 329-362.

Saunders, Rev. John (attrib.), poem accompanying 'Real Life in Sydney', lithograph, with letterbook 1834-1847, Mitchell Library, Sydney.

Sydney Gazette and New South Wales Advertiser, 1803-1842.

Tench, Watkin 1979[1789 and 1793], A Narrative of the Expedition to Botany Bay and A Complete Account of the Settlement at Port Jackson, published as Sydney's First Four Years, LF Fitzhardinge (ed), Library of Australian History, Sydney.

Watson, Frederick (ed) 1914-1925, Historical Records of Australia, series 1, volume 1, Library Committee of the Commonwealth Parliament, Sydney.

White, John 1962[1790], Journal of a Voyage to New South Wales, Angus and Robertson, Sydney.

Worgan, George, Letter written to his brother Richard Worgan, 12-18 June 1788, with journal fragment 20 January 1788 - 11 July 1788, Mitchell Library, Sydney. 
ABORIGINAL HISTORY 2011 VOL 35

\section{Secondary sources}

Attenbrow, Val 2002, Sydney's Aboriginal Past, University of New South Wales Press, Sydney.

Brock, Peggy 2007, 'Nakedness and clothing in early encounters between Aboriginal people of Central Australia, missionaries and anthropologists', Journal of Colonialism and Colonial History 8(1).

Clendinnen, Inga 2003, Dancing with Strangers, Text Publishing, Melbourne.

Cole, Anna 2010, 'Making a debut: myth, memories and mimesis', in Passionate Histories: Myth, Memory and Indigenous Australians, Frances Peters-Little, Ann Curthoys and John Docker (eds), ANU E Press, Canberra: 205-218.

Donaldson, Tamsin 1985, 'From speaking Ngiyampaa to speaking English', Aboriginal History 9(2): 126-147.

Dutton, Geoffrey 1974, White on Black: The Australian Aborigine Portrayed in Art, Macmillan, Melbourne.

Dyer, Colin 2005, The French Explorers and the Aboriginal Australians 1772-1839, University of Queensland Press, St Lucia, Queensland.

Edmonds, Penelope and Samuel Furphy (eds) 2006, Rethinking Colonial Histories: New and Alternative Approaches, Department of History, University of Melbourne, Melbourne.

Fosten, DSV and Bryan Fosten 1989, The Thin Red Line: Uniforms of the British Army between 1751 and 1914, Windrow and Green, London.

Gilligan, Ian 2008, 'Clothing and climate in Aboriginal Australia', Current Anthropology 49(3): 487-495.

Hansen, David 2007, 'Death dance', Australian Book Review, April 2007: 27-32.

Jones, Philip 2007, Ochre and Rust: Artefacts and Encounters on Australian Frontiers, Wakefield Press, Adelaide.

Karskens, Grace 2009, The Colony: A History of Early Sydney, Allen \& Unwin, Sydney.

Kohen, JL 1993, The Darug and their Neighbours: The Traditional Owners of the Sydney Region, Darug Link in association with Blacktown and District Historical Society, Blacktown, New South Wales. 
Kovacic, Leonarda 2006, 'What photographers saw: Aboriginal people and Australian colonial experience', in Rethinking Colonial Histories: New and Alternative Approaches, Penelope Edmonds and Samuel Furphy (eds): 89-104.

Land, Clare 2006, 'Material histories: clothing, control and resistance on missions, 1910-1920', in Rethinking Colonial Histories: New and Alternative Approaches, Penelope Edmonds and Samuel Furphy (eds): 185-202.

Maynard, Margaret 1991, 'Terrace gowns and shearers' boots: rethinking dress and public collections', Culture and Policy 3(2): 77-84.

- 1994, Fashioned from Penury: Dress as Cultural Practice in Colonial Australia, Cambridge University Press, Cambridge.

- 2006, 'Dress for dissent: reading the almost unreadable', Journal of Australian Studies 89: 103-112.

McBryde, Isabel 1989, 'To establish a commerce of this sort: cross-cultural exchange at the Port Jackson Settlement', in Studies from Terra Australis to Australia, John Hardy and Alan Frost (eds), Highland Press and Australian Academy of the Humanities, Canberra: 169-182.

National Museum of the American Indian, 'Wool Trade Cloth in the Collection of the National Museum of the American Indian, Glossary', 2001, <http:/ / www.nmai.si.edu/wooltrade/glossary.shtml>

Peters-Little, Frances, Ann Curthoys and John Docker (eds) 2010, Passionate Histories: Myth, Memory and Indigenous Australians, ANU E Press, Canberra.

Rosenthal, Michael 2000, 'The extraordinary Mr Earle', in The World Upside Down: Australia 1788-1830, Michelle Hetherington and Seona Doherty (eds), National Library of Australia, Canberra.

Rowse, Tim 1991, 'Interpretive possibilities: Aboriginal men and clothing', Cultural Studies 5(1): 1-13.

Russell, Penny 2010, Savage or Civilised? Manners in Colonial Australia, University of New South Wales Press, Sydney.

Shellam, Tiffany 2009, Shaking Hands on the Fringes: Negotiating the Aboriginal World at King George's Sound, University of Western Australia Press, Perth.

Smith, Digby 2007, An Illustrated Encyclopedia of Uniforms of the Napoleonic Wars, Lorenz Books, London.

Smith, Keith Vincent 1992, King Bungaree: A Sydney Aborigine Meets the Great South Pacific Explorers, 1799-1830, Kangaroo Press, Sydney. 
ABORIGINAL HISTORY 2011 VOL 35

- 2001, Bennelong: The Coming in of the Eora, Sydney Cove 1788-1792, Kangaroo Press, Sydney.

Taussig, Michael 1993, Mimesis and Alterity: A Particular History of the Senses, Routledge, New York.

Thomas, Nicholas 1999, Possessions: Indigenous Art/Colonial Culture, Thames and Hudson, London.

Watson, Iris 1998, 'Naked peoples: rules and regulations', Law Text Culture 4(1): $1-17$.

Wilcox, Craig 2009, Red Coat Dreaming: How Colonial Australia Embraced the British Army, Cambridge University Press, Melbourne. 